\title{
A Tale of Two Cities: An Examination of Medallion Prices in New York and Chicago*
}

\author{
Sutirtha Bagchi ${ }^{\dagger}$
}

January 31, 2017

*All links referenced in footnotes were current as of 1/14/2017. I am grateful to Allan J. Fromberg, Deputy Commissioner for Public Affairs, Taxi and Limousine Commission of New York City for answering questions pertaining to New York medallions and to Mandrita Bagchi, Sebastien Bradley, Jeffrey L. Hoopes, Christopher Kilby, and Evan Rawley for comments on a draft of the paper. All errors remain my own.

${ }^{\dagger}$ Sutirtha Bagchi: Department of Economics, Villanova University, Villanova, PA, USA (sutirtha.bagchi@villanova.edu). Ph: (610)519-7799. 


\title{
A Tale of Two Cities: An Examination of Medallion Prices in New York and Chicago
}

\begin{abstract}
This paper examines the institution of taxicab medallions in two of the largest cities of the U.S.: New York and Chicago and changes in the prices of those medallions during the period 2009-2016 (for New York City) and 2007-2016 (for Chicago). We document a drop of roughly $50 \%$ in the prices of these medallions in New York and roughly $80 \%$ in Chicago from their peak in $2013 / 2014$ to the present. We also find that medallion prices are positively correlated with taxicab revenues and negatively correlated with proxies for the intensity of adoption of Uber and Lyft in both cities.
\end{abstract}

Keywords: Taxicab medallions; Transportation Network Company; Uber; Lyft

JEL codes: L43 (Legal Monopolies and Regulation or Deregulation); L51 (Economics of Regulation); G14 (Information and Market Efficiency); M13 (New Firms \& Startups) 


\section{Introduction}

Government regulation is a ubiquitous feature of life in a modern economy. Governments at various levels - federal, state, and local - regulate industries, primarily through a host of regulatory agencies. Such regulation, while often conceived of as a response to market failures such as natural monopolies, externalities, or information asymmetries, may end up being subject to capture by the regulated industry and work primarily to benefit powerful stakeholders in the regulated industry (Stigler, 1971; Posner, 1975; Peltzman, 1976, 1993). Technological change may also interact with the regulatory regime and make some forms of regulation obsolete, or at least less relevant, than when the regulations were originally conceived.

This paper focuses on an industry where technology has interacted with the regulatory regime in ways that were unanticipated until recently: the taxicab industry. In particular, it focuses on the effects that the entry of Transportation Network Companies (TNCs) such as Uber and Lyft have had on the price of a taxicab medallion in two of the largest cities of the U.S.: New York and Chicago. Medallions are "small metal plates attached to the hood of a taxi," that confer it the right to pick-up passengers anywhere within the boundaries of a city. ${ }^{1}$ By law, taxicabs with medallions are the only vehicles authorized to pick up passengers by street hail anywhere within city limits. In New York City and Chicago, affixing a medallion continues to be a requirement for operating a taxicab and given the constraints on the number of medallions outstanding, prices of medallions had shot up to $\$ 1.2$ million (in New York) and over $\$ 350,000$ (in Chicago) as of 2013. Since then, prices have fallen by about 50\% in New York City and about $80 \%$ in Chicago and there has been a rapid increase in the number of medallions which have been foreclosed by lenders as evidenced in Figure 1.

[Figure 1 about here.]

In order to account for the observed price drops of medallions, the paper examines important recent developments in the regulation of taxicabs and the evolving regulatory framework towards TNCs. Using data on average daily revenues of taxicabs which are available for New York City for the period January 2010 - November 2016, we find that the observed drop in taxicab revenues explains between a third and two-fifths of the drop in medallion prices over this

\footnotetext{
${ }^{1}$ As defined in the New York City 2014 Fact Book, http://www.nyc.gov/html/tlc/downloads/pdf/2014_taxicab_fact_book.pdf.
} 
period. While data pertaining to the adoption of Uber and Lyft are unavailable given their status as private entities, we use a novel source of data to proxy for the popularity and likely adoption of TNCs, viz. Google Trends. Following Wu and Brynjolfsson (2015) who use Google trends data to demonstrate how online search can be used to predict future economic trends and provide evidence that queries submitted to Google's search engine are correlated with both the volume of housing sales as well as the Case-Shiller house price index, we look for searches for keywords such as "Uber" and "Uber driver." We provide evidence that medallion prices in New York City are negatively correlated with the intensity of Google searches for these terms, which likely capture the degree of adoption of Uber in the city. Similar results are obtained for Chicago where we find that medallion prices are positively correlated with average daily farebox revenues and negatively correlated with the intensity of Google searches for terms such as "Uber" or "Uber driver" (or "Lyft" and "Lyft driver").

To the best of my knowledge, there has not been any academic research of how the entry of firms such as Uber and Lyft has affected the economics of the taxicab industry generally or, in particular, how it has affected the price of medallions. Two papers however look at different aspects of this industry vis-a-vis Uber. Cramer and Krueger (2016) compare the fraction of time that drivers have a fare-paying passenger in the car in five cities of the U.S. and find that "on average, the capacity utilization rate is 30 percent higher for UberX drivers than taxi drivers when measured by time, and 50 percent higher when measured by miles.” Building on earlier work (Farber 2015), Brodeur and Nield (2016) examine how the relative ease of getting a cab in New York City in rainy conditions changes following the entry of Uber in that market. Their findings suggest that since Uber's entry in New York, it has become easier to find a ride during rainy weather and attribute that to the use of surge pricing under which passengers pay a higher rate for the Uber service during times of high demand. These higher prices give incentives to Uber drivers to respond on both the intensive (hours worked) and extensive margin (number of Uber drivers working) and provide more rides under inclement conditions. Other papers looking at various facets of the rise of Uber include Hall and Krueger (2016) who provide the first comprehensive analysis of the labor market for Uber's driver-partners and Cohen et al. (2016) who exploit features of Uber's surge pricing algorithm to estimate the elasticity of demand for Uber ( $0.4-0.6)$ and the consumer surplus generated ( $\$ 6.8$ billion for the U.S.). 
The focus of this paper is different: it looks at the incumbent industry and examines how the price and number of taxicab medallion transactions has evolved since the rise of TNCs. An advantage of this setting is that we can exploit it to document how technological shocks can affect traditionally regulated industries and the economic rents accruing to producers in these industries.

The paper proceeds in five sections. The second section provides an institutional background and the growth of regulation in this industry. The following two sections, Sections 3 and 4 describe the data used in the analysis and present the results of that analysis. Given differences in the institutional characteristics of the New York and Chicago taxicab markets, those are analyzed separately in these two sections. Section 5 discusses and offers some concluding remarks.

\section{Institutional Background ${ }^{2}$}

New York City's gasoline-powered taxi industry originated in 1907 when Harry N. Allen fielded 65 French-imported automobiles. There was rapid growth in the following decades. Easy entry into the industry however led to an abundance of taxis, resulting in traffic congestion, farecutting wars, and other unsafe and sometimes illegal activities. The Great Depression worsened these problems by generating an influx of unemployed workers and the number of cabs rose to 21,000 in 1931. To address some of the problems presented by the activities of this industry, in 1937 the City Board of Aldermen, the precursor to the City Council, enacted an ordinance sponsored by Lew Haas that froze the number of taxi licenses at 13,595, the number then outstanding. Even though there was rapid growth in economic activity and population in New York City in the post-World War II era, the number of cabs was kept below its Depression-era level. Even as of 2014, when the last Taxicab Fact Book of New York City was compiled, there were only 13,437 taxi medallions in the city in total.

One unique feature of the New York medallion system resulting from the Haas Act of 1937 was the creation of two different types of taxi medallions: an independent medallion and a minifleet medallion. The owner of an independent medallion may only own one medallion and is required to drive a minimum number of shifts annually. ${ }^{3}$ Owners of independent medallions

\footnotetext{
${ }^{2}$ This section draws on The New York City Taxicab Fact Book (2006) created by Schaller Consulting.

${ }^{3}$ Independent taxicab medallions who bought their medallions after January 6, 1990 were required until mid-
} 
typically operate as owner-drivers who own both the medallion and the vehicle on which it is attached. A second class of medallion taxicab license is a mini-fleet medallion that must be owned in groups of at least two. There are no corresponding requirements that owners of minifleet medallions also serve as drivers of vehicles on which these medallions are attached. Owners of mini-fleet medallions typically own multiple medallions and many maintain a fleet of vehicles that are leased to drivers on a per shift basis. In addition to laying out the overall number of medallions and the classification of medallions in two types, the Haas Act set up a nominal "60/40" ratio of mini-fleet to independent medallions. While in its early years, the taxi industry was regulated by the New York City Police Department, The Taxi and Limousine Commission (TLC) created in 1971 by the City Council has been regulating taxi service in the city ever since.

Chicago regulates the taxicab industry through its Department of Business Affairs and Consumer Protection (BACP). Unlike New York, the city does not impose restrictions on owners of any of its medallions that they also operate the cabs themselves. The total number of medallions for the city is capped at $6,904 .^{4}$

\section{Medallion prices in New York City}

While the overall number of medallions is capped, medallions can trade on a secondary market. Data on medallion sales are available from the New York Taxi and Limousine Commission's website for the period between May 2009 and December 2016.

Before presenting the summary statistics, it is worth describing the construction of the sample analyzed in the paper. In total we observe 3,237 medallions traded between May 2009 and December 2016. However, most trades do not take place at arms-length; for example, many involve transfers within a family or partnership splits and are recorded at prices of $\$ 0$ or $\$ 1$. Eliminating all such trades, we obtain a sample of 1,163 medallion trades that plausibly occur at arms-length. Trades can take two forms: asset sales or stock transfers. We only consider asset sales because as the TLC notes: "Stock transfers are typically partial sales for a percentage of

2011 to drive their taxicabs a minimum of 210 nine-hour shifts per year. In mid-2011, those rules were changed to allow drivers to meet the requirement by driving 180 nine-hour shifts per year and allowing individual owners who were 62 (or older) and had driven for at least 10 years to reduce their work schedule to 150 seven-hour shifts per year. (http://www.nyc.gov/html/tlc/downloads/pdf/owner_must_drive_version_10.pdf)

${ }^{4} \mathrm{https}$ //www.washingtonpost.com/news/wonk/wp/2014/06/20/taxi-medallions-have-been-the-best-investment-inamerica-for-years-now-uber-may-be-changing-that/?utm_term =.835c57fec233 
ownership. Sometimes, these are just smaller components of larger or more complex transactions that don't even necessarily involve medallions."5 Dropping all stock transfers from the sample of arms-length trades results in a sample of 1,103 asset sales of medallions. Finally, within each category of medallions - independent and mini-fleet (or corporate), we have three sub-categories: "Unrestricted", "Accessible"6, and "Alternative Fuel."7 Given the lack of comparability across these three sub-categories, this paper, like most TLC tabulations on the topic, analyzes only the 1,078 trades which involve "Unrestricted" medallions. As independent and mini-fleet medallions operate under a somewhat different set of rules, we analyze these two medallion classes separately. ${ }^{8}$

To summarize, we have 3,237 medallions traded over the sample period of which 1,163 are plausibly at arms-length. Of those medallions traded, 1,103 are asset sales and of those 1,078 involve sales of "Independent Unrestricted" or "Corporate Unrestricted" medallions. Although these 1,078 medallions transacted represent only $33.3 \%$ of all medallions traded during the sample period, they represent $80.9 \%$ of overall transaction volume. Panel A of Table 1 presents the summary statistics for all arms-length transactions involving independent medallions while Panel B of Table 1 presents the summary statistics for all arms-length transactions involving mini-fleet medallions.

\section{[Table 1 about here.]}

To someone unfamiliar with this industry, the first revealing observation are the high prices of these medallions. Independent medallions transacted at a median price of $\$ 980,000$ as recently as 2014 while mini-fleet medallions hit their high mark of $\$ 1,200,000$ a year earlier in 2013. The second observation, speaking to the importance of technological disruption to the industry, is the significant drop in prices of medallions from their peak values. Between 2014 and 2016, medallion prices have come down by $42 \%$ in the market for independent medallions and

\footnotetext{
${ }^{5}$ Personal communication with Mr. Allan J. Fromberg of the TLC on 01/18/2017.

6 "All owners of accessible medallions must hack-up a Commission-approved accessible vehicle. As an accessible taxicab medallion owner, you are responsible for making sure that every accessible vehicle driver has a certificate of completion from a Commission-approved training course in passenger assistance techniques and sensitivity training. You must pay for this training." (http://www.nyc.gov/html/tlc/html/industry/accessible_taxicab_medallion_owners.shtml)

7"Alternative Fuel Medallion is a Restricted Medallion valid for use only with a vehicle powered by compressed natural gas or a hybrid electric vehicle...” (http://rules.cityofnewyork.us/content/alternative-fuel-vehiclespecifications)

${ }^{8}$ The term "Mini-fleet medallions" and "Corporate medallions" are used interchangeably in the paper.
} 
47\% for mini-fleet medallions. Reflecting a drying up in the financing for these medallions, the number of transactions itself has shrunk much more than the drop in prices. While the number of transactions has gone down consistently since 2011 in the market for independent medallions, the number of transactions has been going down since 2010 in the market for mini-fleet medallions. The fourth and final observation is the persistent gap in prices of mini-fleet and independent medallions. While this gap has reduced in recent years as medallion prices have come down in general, over the 7-year period between 2010 and 2016, on average mini-fleet medallions traded for about $\$ 200,000$ more than independent medallions, reflecting their greater flexibility in use.

We dig deeper into our finding that there was a large drop in the prices of medallions and look at what may have contributed to that drop. The entry of Uber and Lyft in the market are obvious explanations but it is not clear whether that suffices as an explanation. Uber entered the New York City market in May 2011 with its product, UberBLACK, and rolled out a cheaper version, UberX, in September 2011. ${ }^{9},{ }^{10}$ However, prices kept rising in the market for independent medallions until 2014 and in the market for mini-fleet medallions until 2013. Other events also occurred during our sample period: for example, the announcement of a "Five Borough Taxi Plan” by Mayor Bloomberg in January 2011, followed by passage of a bill by the New York State Legislature in June 2011. The rationale for introduction of this program was that residents of New York City's boroughs outside of Manhattan had fewer opportunities to conveniently hail a cab on the street and under this proposed program, a new class of taxi drivers would be allowed to pick up street hail passengers in all parts of the city except the airports and the Manhattan core (south of West 110th Street and East 96th Street). ${ }^{11}$ In December 2011, Governor Cuomo signed the bill into law but the TLC did not begin issuing new licenses under this program until June 2013 when the law survived a challenge in the state's highest court, the Court of Appeals. Finally, in September 2015, the Queens Supreme Court ruled that for-hire vehicles (including vehicles on the Uber and Lyft platforms) could use "electronic hails" (as opposed to "street hails") to operate in the city.

\footnotetext{
${ }^{9}$ https://newsroom.uber.com/uber-nyc-launches-service/

${ }^{10}$ Lyft entered the market only in 2014 but considerably fewer rides were taken on Lyft relative to Uber in New York City. http://www.cnbc.com/2014/07/29/lyfts-sacrifice-for-the-sake-of-its-nyc-launch.html

${ }^{11}$ http://www.nyc.gov/html/tlc/html/passenger/shl_passenger_background.shtml.
} 
Given these numerous legal and political developments in the area, it would be challenging, if not impossible, to cleanly identify the effect of any one of these developments on the value of these medallions, especially in the absence of a clearly defined control group. Instead, we first examine a plot of prices and number of transfers and see if any clear patterns emerge from those. Conducting such an examination calls for us to aggregate the data as monthly data may be noisy and there are 9 months (30 months) for which no arms-length transactions occur during the sample period in the market for independent (mini-fleet) medallions. At the same time, aggregating the data at an annual level is also likely to not be useful as a coarse aggregation will mask fluctuations occurring within the course of the year. To balance out these two considerations, we aggregate the data at the quarterly level and examine the number of "Independent Unrestricted" and "Corporate Unrestricted" medallions traded and the median price of those trades.

[Figure 2 about here.]

A look at the figure for independent medallions reveals that prices were rising from the start of the sample period until the second quarter of 2012, where they stayed in a relatively narrow band until the second quarter of 2014 before starting to fall. Prices of independent medallions fell sharply from $\$ 960,000$ to $\$ 840,000$ in the fourth quarter of 2014 and then again from $\$ 690,000$ to $\$ 550,000$ in the first quarter of 2016 . The median price at which the six independent medallions that were traded in the fourth quarter of 2016 was $\$ 525,000$, a price drop of roughly $47 \%$ relative to their peak of $\$ 1$ million. Prices of corporate medallions also rose steadily between 2010 and 2013, plateaued in 2013-2014, and then recorded their sharpest drop in the fourth quarter of 2014 when prices fell from $\$ 1.2$ million to $\$ 950,000$. Prices have kept falling since and as of the fourth quarter of 2016, eight corporate medallions were traded at a median price of about $\$ 625,000$, nearly half of the peak that had been seen as recently as the third quarter of 2014 . The number of transactions also appears to have been severely affected. There were no arms-length transactions of "Corporate Unrestricted" medallions in the first two quarters of 2016. While 16 medallions were traded in the third quarter, all 16 medallions had been foreclosed on by their lenders.

We take another approach to understanding the factors influencing medallion prices in New 
York City. Although we do not observe TNC activity directly, ${ }^{12}$ we are able to observe monthly averages for the number of trips taken daily and daily farebox collections by taxicabs. ${ }^{13}$ These data are available from the New York TLC over the period January 2010 to November 2016, largely overlapping with the period for which we have medallion transaction data (between May 2009 and December 2016). In Figure 3, we first visually examine whether there is relationship between average daily farebox collections and the prices at which medallions trade on the secondary market.

[Figure 3 about here.]

The figure suggests a positive relationship between average daily farebox revenue and the prices at which medallions trade in both the "Independent Unrestricted" and the "Corporate Unrestricted" Medallion markets. In Table 2, we examine this more formally: given that the data on farebox revenues are available on a monthly basis, we collapse the transaction data at a monthly level and examine if there is a positive relationship between the average price for all transactions which occur during a month and farebox collections in that month. In particular, we regress the price at which medallions trade against fares collected (in cols. (1) and (2)) and the number of trips taken on taxicabs (in cols. (3) and (4)). Panel A presents the results for "Independent Unrestricted" medallions while Panel B presents the results for "Corporate Unrestricted" medallions. Finally, columns (1) and (3) use the absolute purchase price (in dollars) as the dependent variable of interest, while columns (2) and (4) use the log of purchase price.

\section{[Table 2 about here.]}

As columns (1) and (2) of Panels A and B of Table 2 illustrate, there is a positive and statistically significant relationship (at the $1 \%$ level) between average daily farebox collections and the price at which medallions trade on the secondary market. This holds true for both independent and mini-fleet medallions. There is also a positive and statistically significant relationship between the average number of trips taken per day on taxicabs and the price at which medallions trade for independent medallions (at the 5\% level) and for corporate medallions (at the $1 \%$ level).

\footnotetext{
${ }^{12}$ Uber and Lyft are private entities which are not required to provide detailed information on rides and ridership.

${ }^{13}$ The TLC makes available monthly metrics including average daily trips and fares collected, active vehicles and drivers, and credit card usage in yellow taxis tabulated from yellow taxi trip data collected through the Taxi Passenger Enhancement Program (TPEP).
} 
We can use the coefficients from Table 2 to perform a back-of-the-envelope calculation of whether the drop in medallion prices can be justified based on the drop in the average daily revenues collected by taxicabs. Average daily revenues aggregated across all New York City taxicabs peaked in 2013 , with the average for the first 11 months being $\$ 6,383,125$. Those revenues declined steadily over the next three years and the average for the first 11 months of 2016 was $\$ 5,260,032$ down about 18 percent. Using this drop in taxicab revenues and the coefficients in column (1) of Table 2, we estimate a decline in the price of "Independent Unrestricted" medallions of about $\$ 148,000$; the corresponding estimate for "Corporate Unrestricted" medallions is about $\$ 185,000 .^{14}$ The actual decline in medallion prices between 2013 and 2016 is considerably larger at about $\$ 355,000$ for "Independent Unrestricted" medallions and about $\$ 575,000$ for "Corporate Unrestricted" medallions. Thus, the observed drop in farebox revenues explains between a third and two-fifths of the drop in medallion prices over this period. ${ }^{15}$ Other factors such as the projected decline in taxicab ridership in the future, drying up of financing for medallions, and a drop in the number of drivers willing to drive taxicabs are also likely to have played a role in explaining this drop in prices.

One of the drawbacks of the analysis presented above is that we lack data on ridership or revenues or the pace of adoption of TNCs in New York City. However, we use a novel source of data to proxy for the popularity and likely adoption of TNCs, viz. Google Trends. Wu and Brynjolfsson (2015) who use Google trends data to demonstrate how online search can be used to predict future economic trends, provide evidence that queries submitted to Google's search engine are correlated with both the volume of housing sales as well as the Case-Shiller house price index. Google Trends has also been used by Berge and Jorda (2011) to examine the utility of the index in classifying data on economic activity into recessions and expansions, by Mayer et al. (2014) to document that Internet searches for the term "Countrywide Modification" spiked following announcement of a settlement involving the firm, and by Kumar et al. (2015) to quan-

\footnotetext{
${ }^{14}$ For independent medallions: 0.132 (from col. (1), Panel A, Table 2) * $(\$ 5,260,032-\$ 6,383,125)=-\$ 148,248$. For corporate medallions: 0.165 (from col. (1), Panel B, Table 2$) *(\$ 5,260,032-\$ 6,383,125)=-\$ 185,310$.

${ }^{15}$ We obtain similar results if we use the coefficients from column (3) where we regress medallion prices against the average number of trips per day. The number of trips taken per day on New York City taxicabs had peaked a year earlier in 2012 at 489,195 and have since fallen by about $26 \%$ in the first 11 months of 2016 to 360,589 . Using this drop in trips on taxicabs and the coefficients in col. (3), we estimate a decline in the price of "Independent Unrestricted" medallions of about $\$ 85,000$; the corresponding estimate for "Corporate Unrestricted" medallions is about $\$ 171,000$.
} 
tify the extent to which the U.S. public seeks out information about macroeconomic conditions online.

In our context, we look for searches originating for four sets of keywords from New York City: "Uber", "Uber driver", "Lyft", and "Lyft driver" as these are likely to capture interest among potential passengers and drivers in signing on to these respective platforms. The numbers made available through Google Trends represent search interest relative to the highest point for a given region and a given time period. A value of 100 denotes the period during which searches for that term peak in popularity. ${ }^{16}$ Figure 4 gives us a sense of the rapid increase in interest in the search terms, "Uber" and "Uber driver" in recent years. The patterns for the terms "Lyft" and "Lyft driver" are similar.

[Figure 4 about here.]

We now use the data obtained from Google Trends to augment the model presented earlier which simply includes farebox revenue collections (or trips per day). In particular, in Table 3 we include the intensity of searches for either the term "Uber" or the term "Uber driver" in New York City as an independent variable. While the following table presents results obtained using farebox revenues, results use trips per day as an alternative measure of the intensity of taxicab usage are available on request.

\section{[Table 3 about here.]}

The results presented in Table 3 indicate the patterns we would expect to see in the data: while medallion prices are higher when farebox revenue collections are higher, they are also negatively correlated with the intensity of Google searches for both terms, "Uber" and "Uber driver", which likely capture the extent of adoption of this service in the city. Interestingly, we note that the coefficient on the term "Uber driver" is statistically significant in all instances (at the 5\% level) and larger in magnitude in comparison to the corresponding coefficient on the term "Uber", consistent with the view that as Uber has grown more popular, owners of medallions have found it more difficult to recruit willing drivers and that has exerted a downward pressure on medallion prices. ${ }^{17}$

\footnotetext{
${ }^{16} \mathrm{~A}$ value of 50 means that the term is half as popular. Likewise a score of 0 means the term was less than $1 \%$ as popular as the peak.

${ }^{17} \mathrm{http}$ :/gothamist.com/2015/08/21/why_yellow_cabs_are_taking_up_all_o.php
} 
We can go further in trying to get a sense of the magnitude of these coefficients on the terms, "Uber" and "Uber driver." For 2013, during the period when taxicab revenues had peaked, the average score for searches for "Uber driver" stood at 2, whereas in 2016, the average score had increased to 73. Multiplying this increase in the score for searches of the term, "Uber driver" with the coefficient in column (3) of Table 3, we obtain an estimated impact on prices in the independent medallion market of about $\$ 65,000$ and about $\$ 133,000$ in the corporate medallion market. ${ }^{18}$ Since the coefficients on farebox collections are practically unchanged between Tables 2 and 3, we can think of the increased search intensity for "Uber driver" as explaining roughly an additional one-fifth of the drop in medallion prices that we observe between 2013 and $2016 .{ }^{19}$

As Figure 4 illustrates, the monthly data on Google searches for these terms exhibit large month-to-month variations which are somewhat hard to reconcile. Therefore in a slightly different approach, we aggregate the data at a quarterly level and examine whether the relationship between medallion prices, taxicab usage, and Google searches for "Uber" or "Uber driver" is borne out in those data as well. They are, as can be seen from Appendix Table A.1, with the coefficients being similar in magnitude and levels of statistical significance to those that we observe in Table 3. It reaffirms our conclusion that higher farebox collections are associated with higher medallion prices while a higher intensity of search for "Uber" (or "Uber driver") likely proxying for the adoption of Uber in the city, is associated with lower medallion prices. We also find that a plot of score for Google searches for the terms "Uber" and "Uber driver", when the underlying data are aggregated at a quarterly level, exhibits fewer variations from one quarter to the next and generally points in the direction of increasing adoption of this app (See Appendix Figure A.1).

\section{Medallion prices in Chicago}

As in New York City, while the overall number of medallions is capped in Chicago, medallions trade on the secondary market. Data on medallion sales are available for the period from 2007 through 2010 from a monthly trade magazine, The Chicago Dispatcher, while data from 2011 through 2016 are available through the city's Department of Business Affairs and Consumer

\footnotetext{
${ }^{18}$ For independent medallions: -919.0 (from col. (3), Panel A, Table 3) * $(73-2)=-\$ 65,172$. For corporate medallions: -1880.6 (from col. (3), Panel B, Table 3) $*(73-2)=-\$ 133,366$. The price drop in the independent and corporate medallion markets between 2013 and 2016 was about $\$ 355,000$ and $\$ 575,000$ respectively.

${ }^{19}$ Independent Medallions:- $\$ 65,172 /-\$ 355,000=18.4 \%$; Corporate Medallions: $-\$ 133,366 /-\$ 575,000=23.2 \%$.
} 
Protection which regulates taxicabs in the city. Chicago does not impose restrictions on the owner of medallions that they drive the cab themselves; thus there is no distinction between independent and mini-fleet (corporate) medallions as was the case in New York City.

For our analysis we start with the entire universe of 3,457 transactions of Chicago taxicab medallions occurring between 1/1/2007 and 12/31/2016. We drop all transactions that we believe do not occur at arms-length (e.g. transactions taking place at artificially low prices such as $\$ 0, \$ 1$, etc.) On dropping such transactions, we are left with a sample of 3,278 transactions which represent $94.8 \%$ of all transactions and $98.4 \%$ of all transaction volume. Table 4 presents the summary statistics for all arms-length transactions that occur during this 10-year period between 2007 and 2016 .

\section{[Table 4 about here.]}

A few observations based on the summary statistics presented in this table: first, while medallion prices rose rapidly during the period under study, they never reached the valuations that medallions had in New York City, reflecting perhaps the underlying differences in the profitability of owing a medallion in these two cities. The maximum price at which a medallion changed hands in Chicago was $\$ 390,000$ in the third quarter of 2012. In contrast, the maximum price at which a medallion was traded in New York City was $\$ 1.32$ million in the second quarter of 2013. Second, we see that regardless of the measure used, medallion prices in Chicago peaked in 2013 at about $\$ 350,000$. Medallion prices declined modestly in 2014 to about $\$ 325,000$, before declining materially to about $\$ 250,000$ in 2015 eventually crashing to a price of $\$ 60,000$ in 2016 . As in New York City, perhaps reflecting a drying up of the financing for these medallions, the number of transactions shrunk much more than the drop in prices. The number of transactions was highest in 2007 at the start of the sample period. After reaching a relative high of 507 medallions traded in 2012, the number of transactions dropped in 2013 to 361, before slowing down further to only 89 in 2014. Thus, even though prices held steady between 2012 and 2014, this was based on, relatively speaking, very few transactions. After only 12 transactions took place in 2015 , we see 30 transactions occur in 2016 but at a much lower median price of $\$ 60,000$, lower than what we see at the start of the sample period and roughly 80 percent below their peak of $\$ 350,000$. While the Chicago medallion data do not allow us to observe if the medallion 
transactions involved foreclosures, media reports indicate that foreclosures have grown rapidly in recent years in Chicago as well. ${ }^{20}$

As in New York City, the taxicab industry in Chicago has been impacted by the advent of TNCs, although exactly attributing how much of the decline is due to that is complicated. Uber arrived in Chicago in 2011 with its UberBLACK product, followed by the launch of UberX in 2013. ${ }^{21}$ Lyft launched in 2013 and has since then, competed aggressively with Uber. ${ }^{22}$ Around Fall of 2013, the city also announced an auction of 50 new medallions to raise revenue setting a minimum bid price of $\$ 360,000$, but the city failed to attract buyers at that price leading to nervousness among some in the industry. ${ }^{23}$

In terms of the legal and regulatory landscape, there were numerous developments during this period under consideration. In May 2014, the Illinois State Senate passed ride-sharing rules requiring, for example, that commercial ride-sharing companies carry primary commercial liability insurance equal to taxis and that drivers working more than 18 hours per week get public chauffeurs licenses and undergo the same criminal background checks and drug testing as taxi drivers. ${ }^{24}$ However, Governor Pat Quinn vetoed the bill arguing against "a one-size-fitsall approach to a service that is best regulated at the local level." ${ }^{25}$ In 2014, the Chicago City Council adopted regulations governing TNCs, but they were challenged by a coalition of taxi owners in the U.S. District Court for the Northern District of Illinois for being too lax. In April 2016, the U.S. District Court rejected an attempt by the city to dismiss the lawsuit allowing it to proceed. However, following an appeal by the city, the 7th U.S. Circuit Court of Appeals in October 2016 ordered the dismissal of the suit. ${ }^{26}$

Given these numerous developments, it would be challenging, if not impossible, to cleanly identify the effect of any one of these developments on the value of these medallions. Instead, what we do is examine a plot of prices and number of transactions and see if any clear patterns

\footnotetext{
${ }^{20} \mathrm{http} / / /$ www.cpapracticeadvisor.com/news/12289342/uber-lyft-ridesharing-hits-chicago-taxi-business-hard

${ }^{21} \mathrm{https} / / /$ newsroom.uber.com/us-illinois/area/chicago/

${ }^{22} \mathrm{https}$ ://techcrunch.com/2013/05/09/zimride-no-more-lyft-chicago/ \&

http://www.chicagobusiness.com/article/20161209/NEWS10/161209857/lyft-looks-to-dethrone-uber-starting-inchicago.

${ }^{23} \mathrm{https} / /$ www.washingtonpost.com/news/wonk/wp/2014/06/20/taxi-medallions-have-been-the-best-investment-inamerica-for-years-now-uber-may-be-changing-that/?utm_term=.4e009a3b9a44

${ }^{24} \mathrm{https}: / / w w w . w b e z . o r g / s h o w s / w b e z-n e w s / i l l i n o i s-s e n a t e-p a s s e s-r i d e-s h a r i n g-r u l e s / 3792 c 944-f b 01-4 a b 6-a a e 0-$ 3d27a356891b

${ }^{25} \mathrm{http}$ ://www3.illinois.gov/PressReleases/ShowPressRelease.cfm?SubjectID=2\&RecNum=12553

${ }^{26} \mathrm{http} / /$ www.chicagotribune.com/news/local/politics/ct-rahm-emanuel-uber-taxi-ruling-1008-20161007-story.html
} 
emerge from those. We aggregate the data at the quarterly level in conducting this examination as monthly data may be noisy and no transactions occur during 13 months within the span of this 10-year period.

[Figure 5 about here.]

What comes out as we examine this figure echoes our impressions from Table 4. We see that the market for taxicab medallions had been growing thinner in years prior to the decline in prices of medallions. The sharp decline in prices between the fourth quarter of 2015 and the first quarter of 2016 is notable. The median price of a medallion declined from $\$ 194,000$ in the fourth quarter of 2015 to $\$ 50,000$ in the first quarter of 2016 before recovering somewhat to $\$ 67,500$ in the fourth quarter of 2016 . The median price for all of 2016 was $\$ 60,000$.

We repeat our previous analysis using Google Trends to proxy for the adoption of Uber and Lyft in Chicago. While these data are available at a monthly level from 2004 onwards, unlike New York City, data on taxicab farebox revenues and rides taken are unavailable for Chicago for our period of study between 2007 and 2016. Data on farebox collections for the city are available only for the period between January 2013 and June 2016. Fortunately, this overlaps with the launch of UberX and Lyft in Chicago. As before, we look for searches originating from Chicago for four sets of keywords: "Uber", "Uber driver", "Lyft", and "Lyft driver" as these are likely to capture interest among Chicago residents in signing on to these respective platforms as passengers and drivers. Figure 6 gives us a sense of the rapid increase in interest in searches for the terms, "Uber" and "Uber driver." The patterns for the terms "Lyft" and "Lyft driver" are similar and are presented in Figure 7.

[Figure 6 about here.]

[Figure 7 about here.]

We use these data obtained from Google Trends to examine the effect that the adoption of these apps has on medallion prices. In particular, in Panel A of Table 5 we regress medallion prices for all arms-length transactions occurring over a month against monthly farebox revenues and the intensity of searches for the terms "Uber" or "Uber driver" in that month. As was noted earlier, Lyft has competed more vigorously with Uber in Chicago as compared to New York City and hence in the interest of completeness, we also present results using the intensity of searches for either the term "Lyft" or the term "Lyft driver" in Panel B of Table 5. 


\section{[Table 5 about here.]}

The results presented in Table 5 indicate the patterns we would expect to see in the data: while medallion prices are higher when farebox revenue collections are higher, they are also negatively correlated with the intensity of Google searches for the terms, "Uber" and "Uber driver", which likely capture the extent of its adoption in the city. Similar results are obtained in Panel B, when we examine the intensity of Google searches for the terms, "Lyft" and "Lyft driver". As before, given the large fluctuations in the monthly data on Google searches for these terms, in an alternative approach we aggregate the data at a quarterly level and look for the presence of a relationship between medallion prices, taxicab usage, and Google searches for "Uber" or "Uber driver" (or "Lyft" or "Lyft driver"). The results obtained are very similar to those presented in Table 5 and are included as Appendix Table A.2.

In terms of quantifying the magnitude of these impacts, we note that daily revenues across all Chicago taxicabs, averaged for the first six months of 2016 stood at $\$ 877,568$, practically unchanged from daily taxicab revenues during the corresponding period of 2013 when they were $\$ 895,145$. Daily taxicab revenues in fact were higher during the first six months of 2014 and 2015 at roughly $\$ 1.1$ million. Therefore, the large drop in medallion prices between 2013 and 2016 cannot be explained by the changes in taxicab revenues taking place during those years. However, the increasing adoption of Uber and Lyft seems to have significant predictive power. Considering Uber, the average score for Google searches for "Uber" stood at 10 in 2013 and had increased to 88 in 2016. Using the coefficient on the term "Uber" in column (1) of Panel A of Table 5, we see that this increased search intensity for "Uber" could be thought of as explaining roughly $\$ 250,000$ of the price drop we observe. ${ }^{27}$ Median prices of taxicab medallions declined from $\$ 357,000$ in 2013 to $\$ 60,000$ in 2016 . Thus, the increasing adoption of Uber, likely accounts for a large fraction of the drop in medallion prices in the city of Chicago.

Having examined the New York and Chicago markets separately, we can make one final observation that manifests itself in both markets. There appears to be an inverse relationship between the dollar volume of transactions conducted over a quarter and the dispersion of prices during that period. Figure 8 plots the data while Table 6 presents the results from six different

\footnotetext{
${ }^{27}-3245.5$ (from col. (1), Panel A, Table 5) $*(88-10)=-\$ 253,149$. We obtain similar results if we use the increase for the search terms, "Uber driver" or "Lyft" or "Lyft driver."
} 
regressions - two each for the New York independent medallion market, the New York mini-fleet medallion market, and the Chicago medallion market. In these regressions, we examine the relationship between a commonly used measure of dispersion, the coefficient of variation, with overall transaction activity.

[Figure 8 about here.]

[Table 6 about here.]

Across the three panels of Figure 8 and all columns of Table 6 , we observe a negative relationship between price dispersion, as measured by the coefficient of variation, and the overall dollar volume of transaction in that market; furthermore, this relationship is statistically significant in four of the six columns. This is likely due to the role of uncertainty in the market for medallions: as potential buyers of medallions wait on the sidelines for the regulatory and technological uncertainty to reduce, the market may be susceptible to trades initiated by relatively few traders with wildly varying expectations. Such behavior may result in fewer transactions going hand-in-hand with a larger dispersion in prices. $^{28}$

\section{Discussion and Conclusions}

As we look at the valuation of taxicab medallions over time, it is natural to reflect on whether taxicab medallions were over-valued, especially during their peak in 2013 and 2014, relative to their underlying true valuations. That is not an easy question to answer given that there were numerous proposals and court challenges that were all deployed in a bid to slow, and perhaps even stop, the growth of TNCs and it was unclear what form the new set of regulations enacted on the TNC industry would be. As was seen recently, following the outcome of an election in 2016 in Austin in which voters reaffirmed a city council ordinance that all drivers be fingerprinted and undergo criminal checks, Uber and Lyft decided to exit the Austin market. ${ }^{29}$

\footnotetext{
${ }^{28}$ I examine this relationship between price dispersion and trading activity, using the number of medallions traded as the dependent variable as opposed to the dollar volume of such transactions. While we obtain negative coefficients across all specifications for both markets, the coefficients in those regressions are generally not statistically significant. In a very different context (housing markets in Hong Kong), Yiu et al. (2008) make a similar observation and note that their measure of house price dispersion is negatively and significantly correlated with the volume of transactions that take place in the prior 10-day and 30-day period window.

${ }^{29} \mathrm{http}$ ://fortune.com/2016/05/08/uber-lyft-austin-fingerprints/
} 
Apart from legal and regulatory uncertainty, there were differences in opinion among industry participants and outside experts regarding the pace of technology adoption and how fast TNCs could grow. A well-known commentator for example noted in June 2014 after Uber had raised money from investors at a valuation of $\$ 17$ billion that his best estimate for Uber's riskadjusted value was $\$ 5.9$ billion. ${ }^{30}$ Only two years later, Uber raised money again from investors at a valuation of $\$ 66$ billion. ${ }^{31}$ Clearly, owners of taxicab medallions were not the only group of individuals unable to anticipate the sharp growth in the rise of Uber (and to some extent, Lyft) and the drop in medallion prices observed may be seen as a response to Uber's faster-thananticipated growth.

Regarding the differential price declines in the price of medallions in Chicago relative to New York City, one can offer some tentative arguments for why that might have been the case. First, as pointed out by Cramer and Krueger (2016) in their study of utilization rate of cab drivers and Uber drivers, "New York City is an apparent outlier in that the capacity utilization rates of taxi and UberX drivers are much more similar in New York than in other cities." The authors speculate that the high population density of New York City might support more efficient matching of taxis and passengers through street hailing, which by law is limited to only taxis, than is the case in other cities. This is likely to be true since taxi activity in New York is centered on Manhattan, where $90.3 \%$ of taxi pick-ups occur (Taxicab Fact Book, 2014, p. 5). In that case, the prices of taxicab medallions might not fall by as much because as long as the right to hail a vehicle off the street is limited to taxicabs, medallions in New York City will retain value. The second explanation that may play a part in the differential price response is the regulatory environment in the two cities. New York City mandates drug testing and fingerprinting of all commercial drivers and requires them to get a chauffeur license and undergo a 24 hour education course prior to driving for TNCs. ${ }^{32}$ Requirements in Chicago appear more modest in that regard as they do not require any one of those four elements.

The paper highlights the significant effects that technological innovations can have on the fortunes of an established industry, especially one that was the beneficiary for an extended period of time of government regulation. However, the article has scratched the surface in terms of what

\footnotetext{
${ }^{30} \mathrm{https}$ //fivethirtyeight.com/features/uber-isnt-worth-17-billion/

${ }^{31} \mathrm{http} / / / \mathrm{www} . w s j . c o m / a r t i c l e s /$ uber-raises-3-5-billion-from-saudi-fund-1464816529

${ }^{32} \mathrm{http}: / / \mathrm{www} . n y c . g o v / \mathrm{html} / \mathrm{tl} / \mathrm{html} /$ industry/drivers.shtml
} 
the future holds. With more moderate prices of taxicab medallions, the cost of leasing a medallion would also go down and the economics may improve for individuals driving cabs inducing drivers to shy away from partnering with TNCs. As has been noted elsewhere, the lack of drivers willing to lease medallions and drive taxicabs (relative to driving their personal vehicle on the Uber and Lyft platforms) has played a significant role in the drop in prices of taxicab medallions. ${ }^{33}$ Going beyond the impact on prices of medallions, one can examine the change in service levels and quality experienced by users of regular taxicabs and of TNCs. All of those should be of interest to economists and remain ripe areas for further exploration.

\section{References}

Berge, Travis J., and Òscar Jordà, 2011, "Evaluating the Classification of Economic Activity into Recessions and Expansions," American Economic Journal: Macroeconomics, 3(2), 246-277.

Brodeur, Abel and Kerry Nield, 2016, "Has Uber Made it Easier to Get a Ride in the Rain?, IZA Discussion Paper No. 9986. Available at SSRN: https://ssrn.com/abstract=2797557.

Cohen, Peter, Robert Hahn, Jonathan Hall, Steven Levitt, and Robert Metcalfe, 2016, "Using Big Data to Estimate Consumer Surplus: The Case of Uber," NBER Working Paper No. 22627.

Cramer, Judd, and Alan B. Krueger, 2016, "Disruptive Change in the Taxi Business: The Case of Uber," The American Economic Review Papers \& Proceedings, 106(5), 177-182.

Farber, Henry S., 2015, "Why You Can't Find a Taxi in the Rain and Other Labor Supply Lessons from Cab Drivers," The Quarterly Journal of Economics, 130(4), 1975-2026.

Hall, Jonathan V. and Alan B. Krueger, 2016, “An Analysis of the Labor Market for Uber's Driver-Partners in the United States,” NBER Working Paper No. 22843.

Kumar, Saten, Olivier Coibion, Hassan Afrouzi, and Yuriy Gorodnichenko, 2015, "Inflation Targeting Does Not Anchor Inflation Expectations: Evidence from Firms in New Zealand," Brookings Papers on Economic Activity, 151-208.

Mayer, Christopher, Edward Morrison, Tomasz Piskorski, and Arpit Gupta, 2014, "Mortgage Modification and Strategic Behavior: Evidence from a Legal Settlement with Countrywide," The American Economic Review, 104(9), 2830-2857.

New York City Taxi and Limousine Commission, 2014, “Taxicab Fact Book," New York City, NY.

Peltzman, Sam, 1976, “Toward a More General Theory of Regulation,” Journal of Law and Economics, 19(2), 211-240.

\footnotetext{
${ }^{33}$ http://gothamist.com/2015/08/21/why_yellow_cabs_are_taking_up_all_o.php
} 
Peltzman, Sam, 1993, "George Stigler's Contribution to the Economic Analysis of Regulation," Journal of Political Economy, 101(5), 818-832.

Posner, Richard, 1975, “The Social Costs of Monopoly and Regulation," Journal of Political Economy, 83(4), 807-827.

Schaller, Bruce, 2006, “The New York City Taxicab Fact Book,” Schaller Consulting, New York, NY.

Stigler, George, 1971, "The Theory of Economic Regulation," Bell Journal of Economics and Management Sciences, 2(1), 1-21.

Wu, Lynn L., and Erik Brynjolfsson, 2014, "The Future of Prediction: How Google Searches Foreshadow Housing Prices and Sales," Economic Analysis of the Digital Economy, (eds.) Avi Goldfarb, Shane M. Greenstein, and Catherine E. Tucker.

Yiu, C. Y., K. F. Man, and S. K. Wong, 2008, "Trading Volume and Price Dispersion in Housing Markets," Journal of Property Research, 25(3), 203-219. 


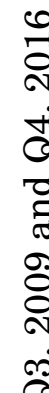

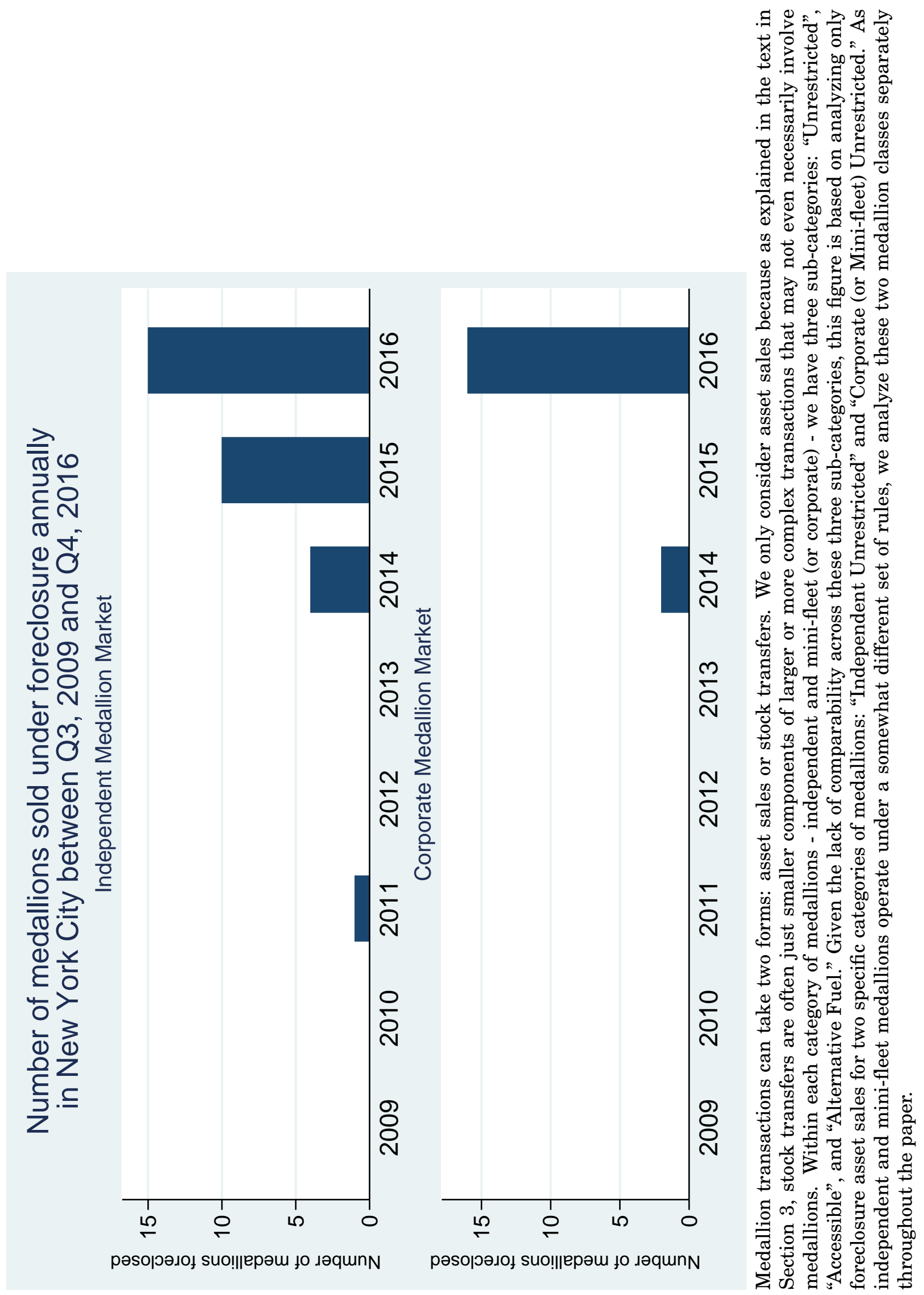


(6)

๑)

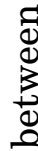

过

Z

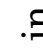

.7.]

.

.

$\stackrel{\pi}{4}$

4

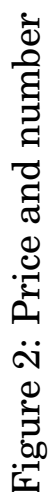
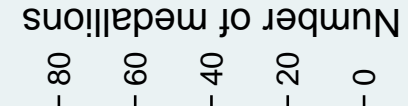

克

눙

$>0$

过

등

이

뜬

๘ึั

음

이

E

느ㅇㅡㅡ

이

ฮั

ह 음

등 엉

สิ 1

థ. .

는

口

ио!ן|ерәш е ґо әо!ıd ие!рәW

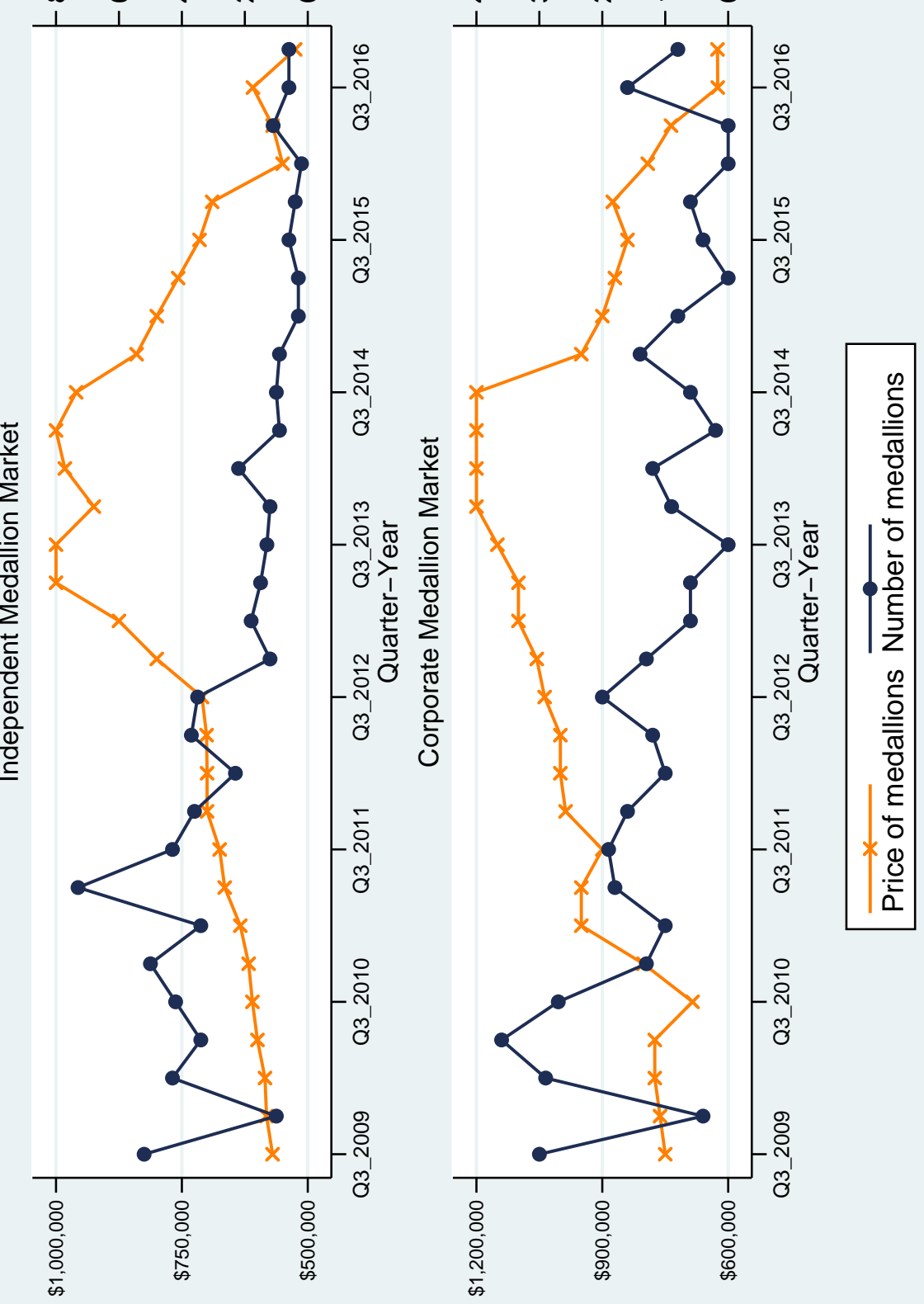

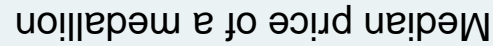

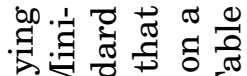

政的

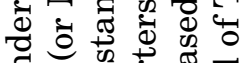

छ

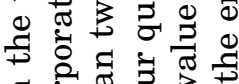

.

రृ

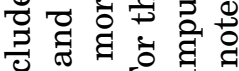

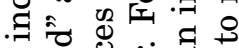

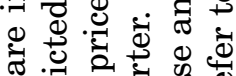

0 获䨌

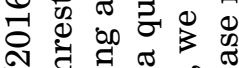

ิั

ลै प्रु

ช。

สี

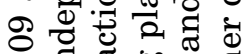

คิ

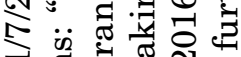

落

ฮี

उ

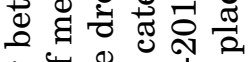

004

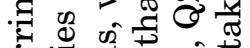

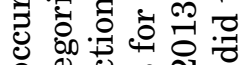

\& U थ

๘

象

तु

क्व

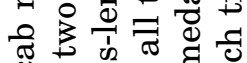

. तु

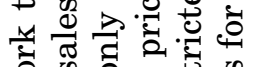

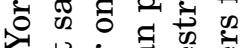

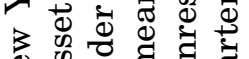

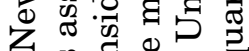

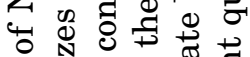

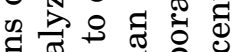

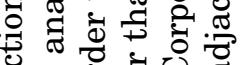
¿

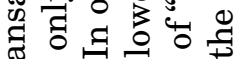
$\ddagger$ Ð 牙些要 胥.

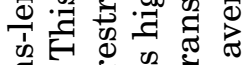
है च สั $\rightarrow \frac{10}{\pi} \cdot \frac{\pi}{5} 80$ ร) 

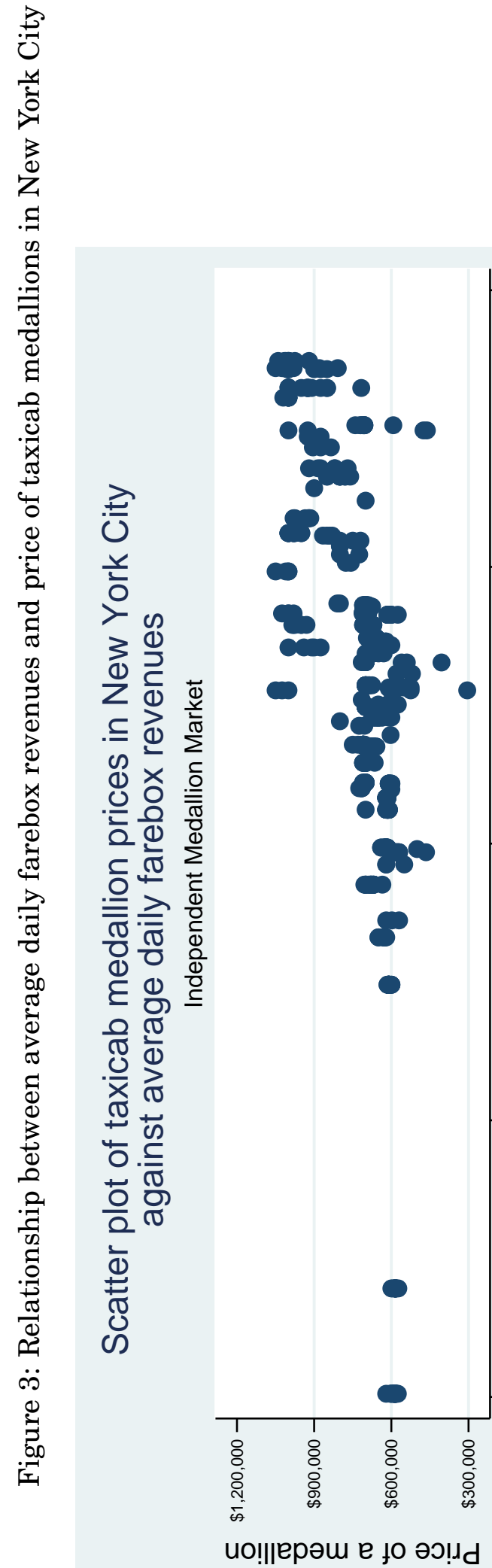
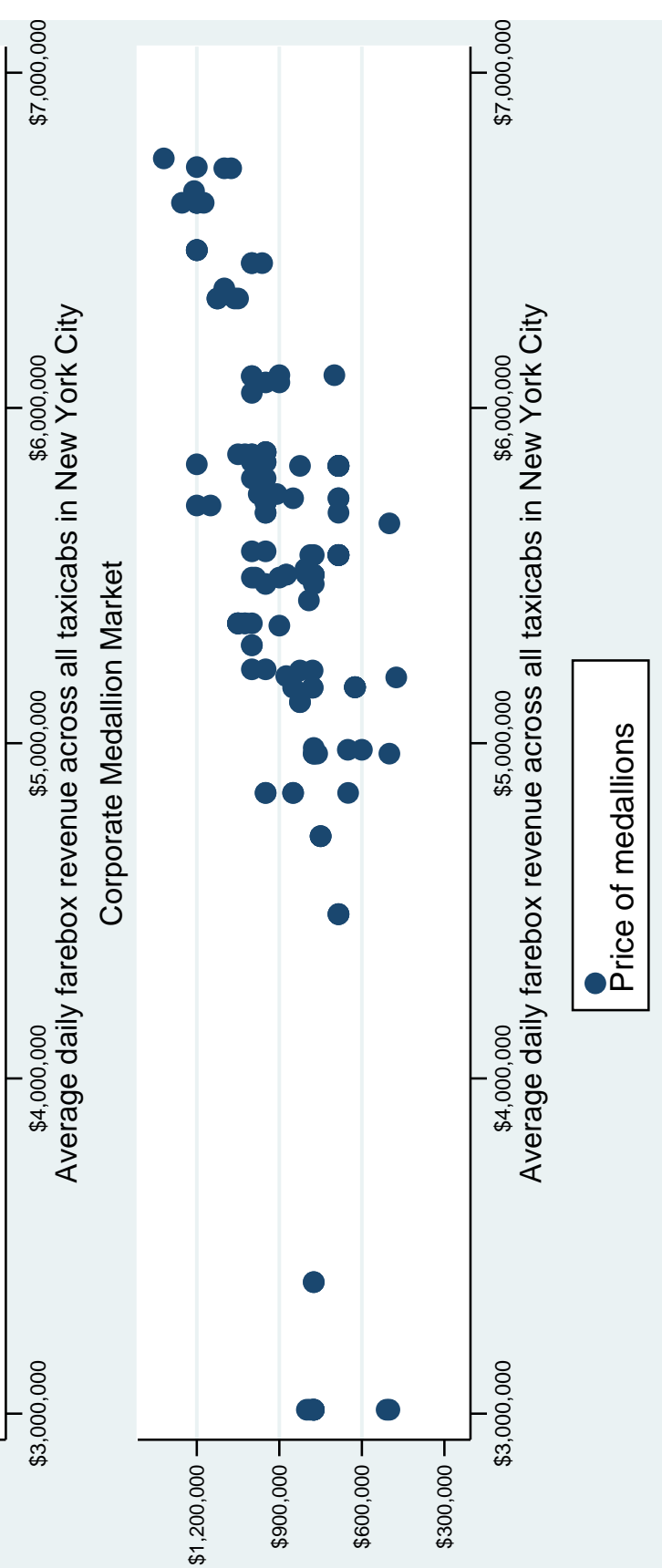

uo!ן|ерәш e fo ә0!גd

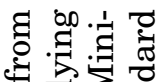

0 늘

过需

ลิ

बं

है

बः

응 웡

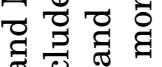

․․ ₹

ণิ

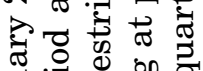

๙ֶ.

สี

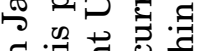

ญ्ञ

कo : वै

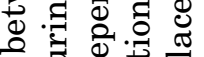

긍 웡

कo

记茪

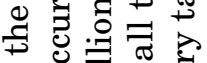

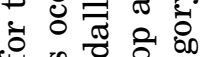
() द्व

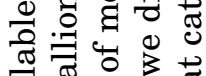
तี कृ की

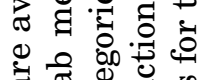
ส D.

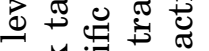
걸 겅 㐁穴

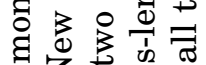
द记䨔

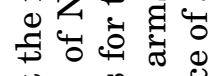
๘ $\infty$ 苟 đ.

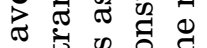

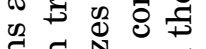
도옳요 苍司离 号向

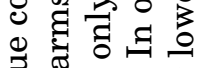
ป

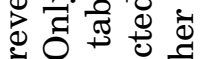
象

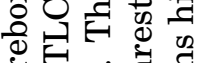
สँ 之元完

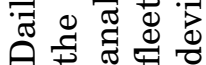




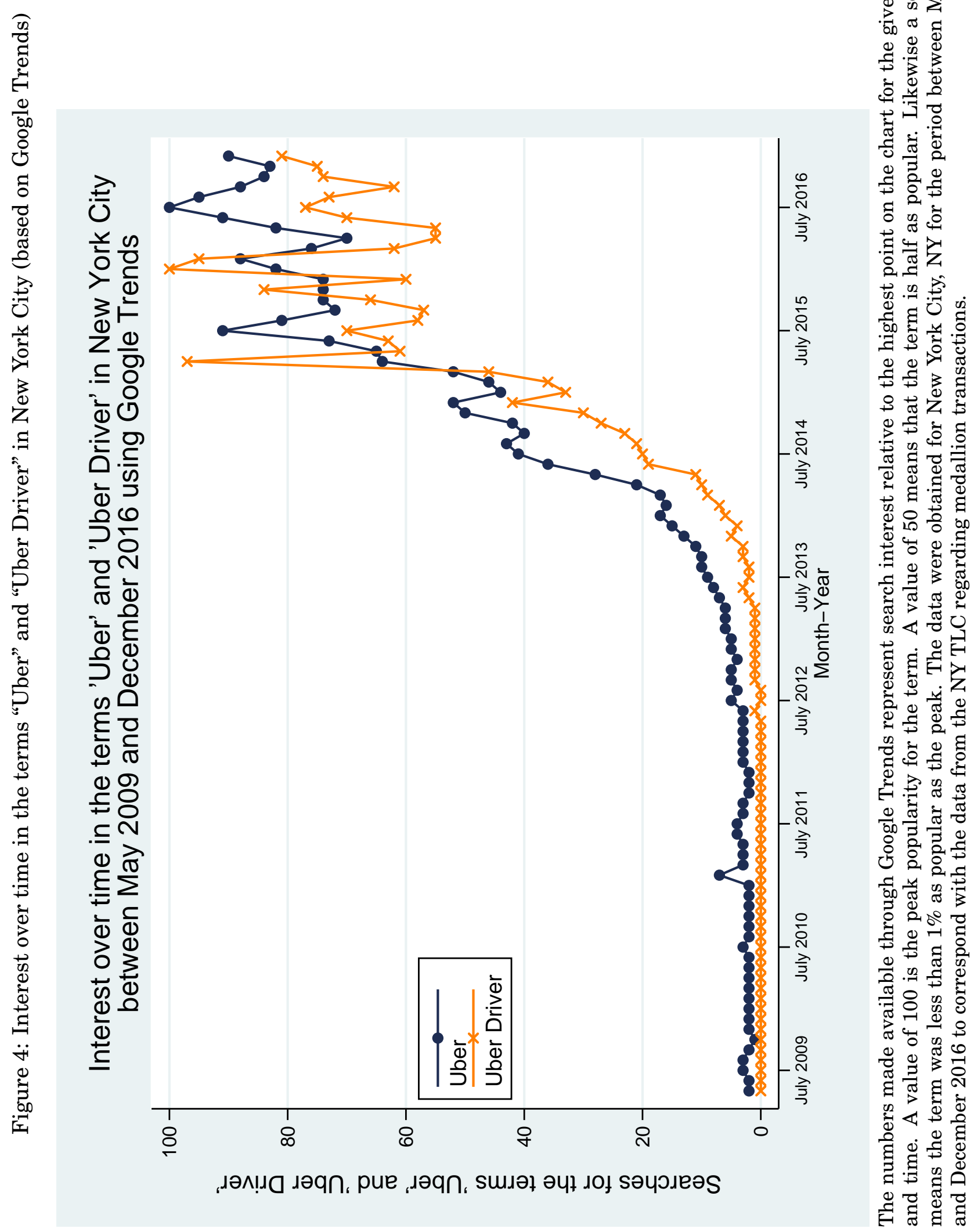




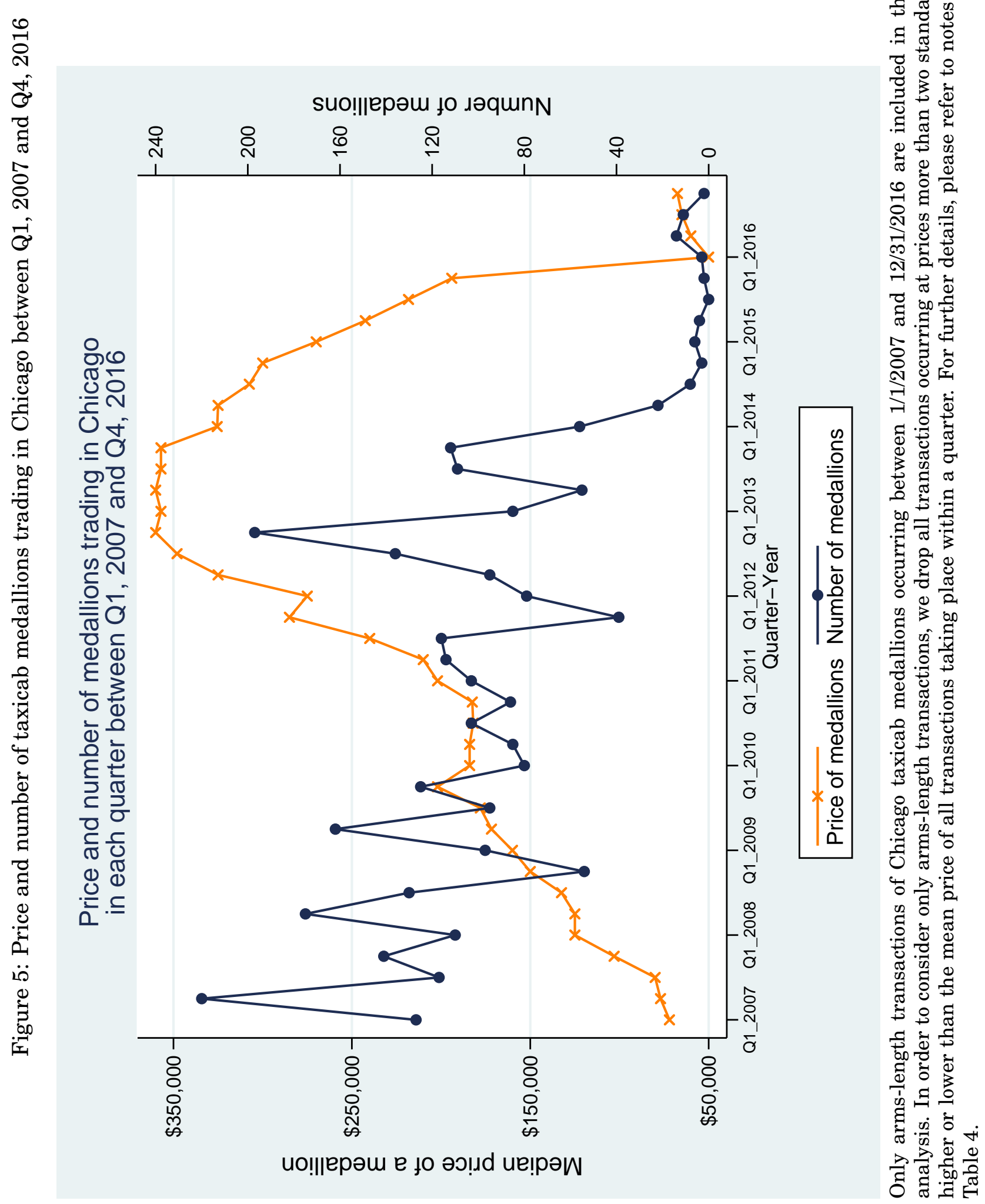




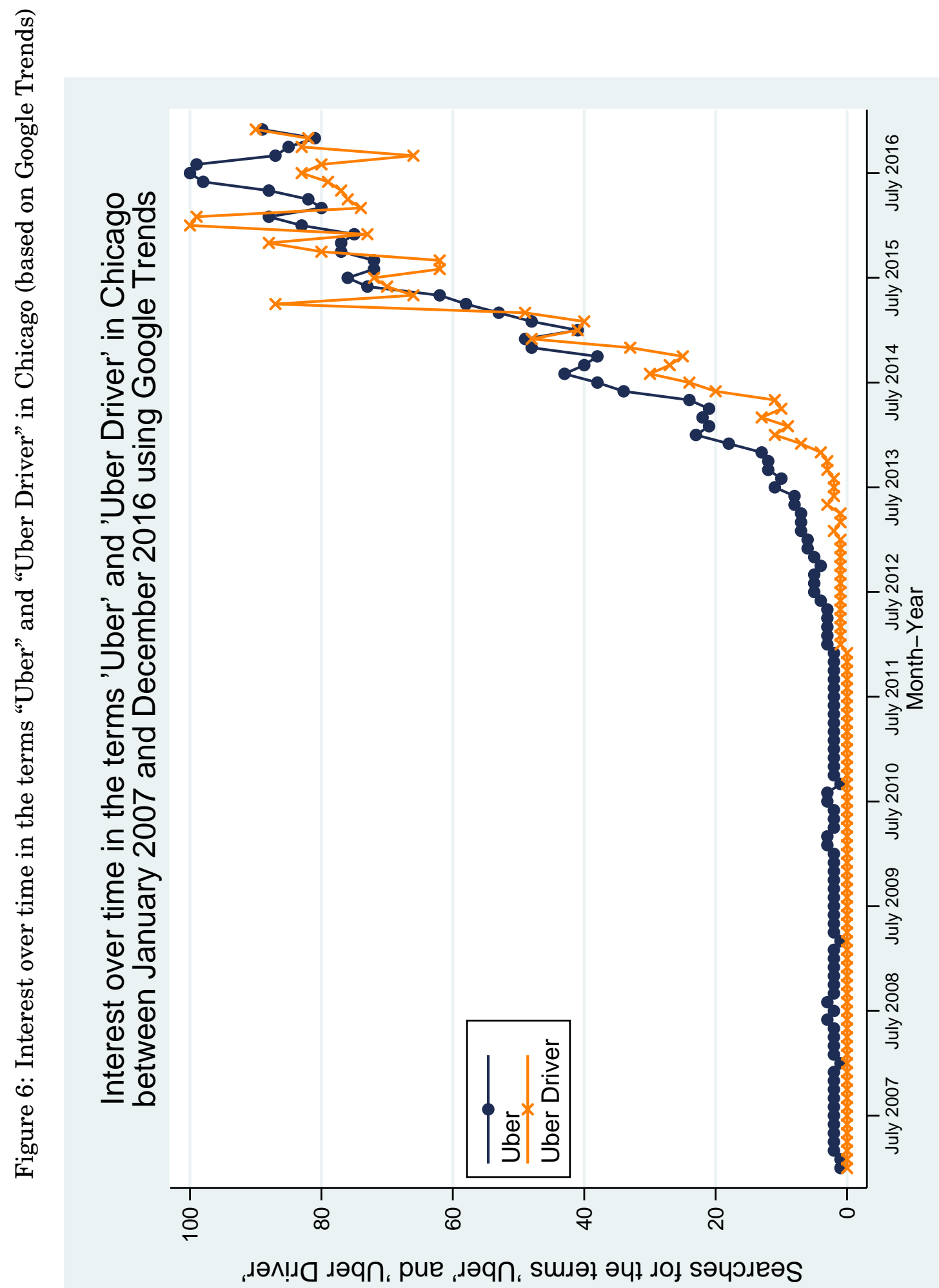

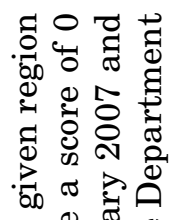

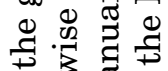

宅

붕

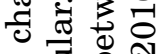

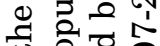

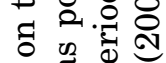

पथ 2

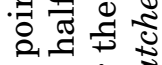

प्र

क्ष

ت 50

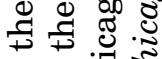

눙

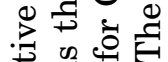

बृ

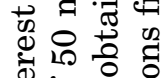

壳

공

ส क « क

苛

है.

웜

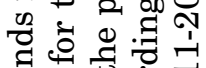

궁

स.द्य 0

के

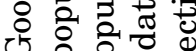

눌 至

का ส

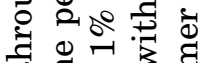

Ф) चี

응. 공 둥

त्र 8 की

उफ

월

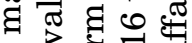

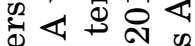

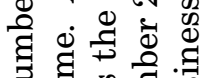
द्व प्व द्व ज्ञ

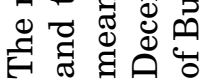




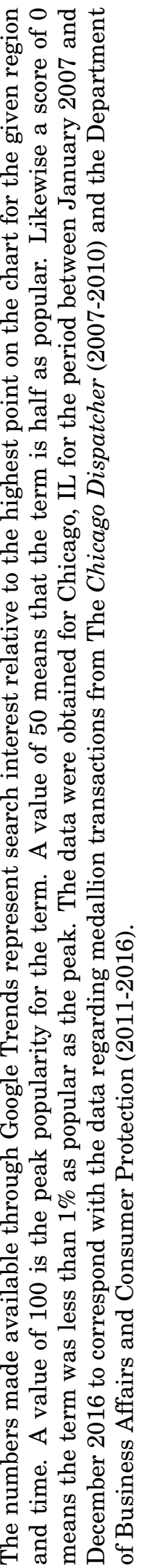




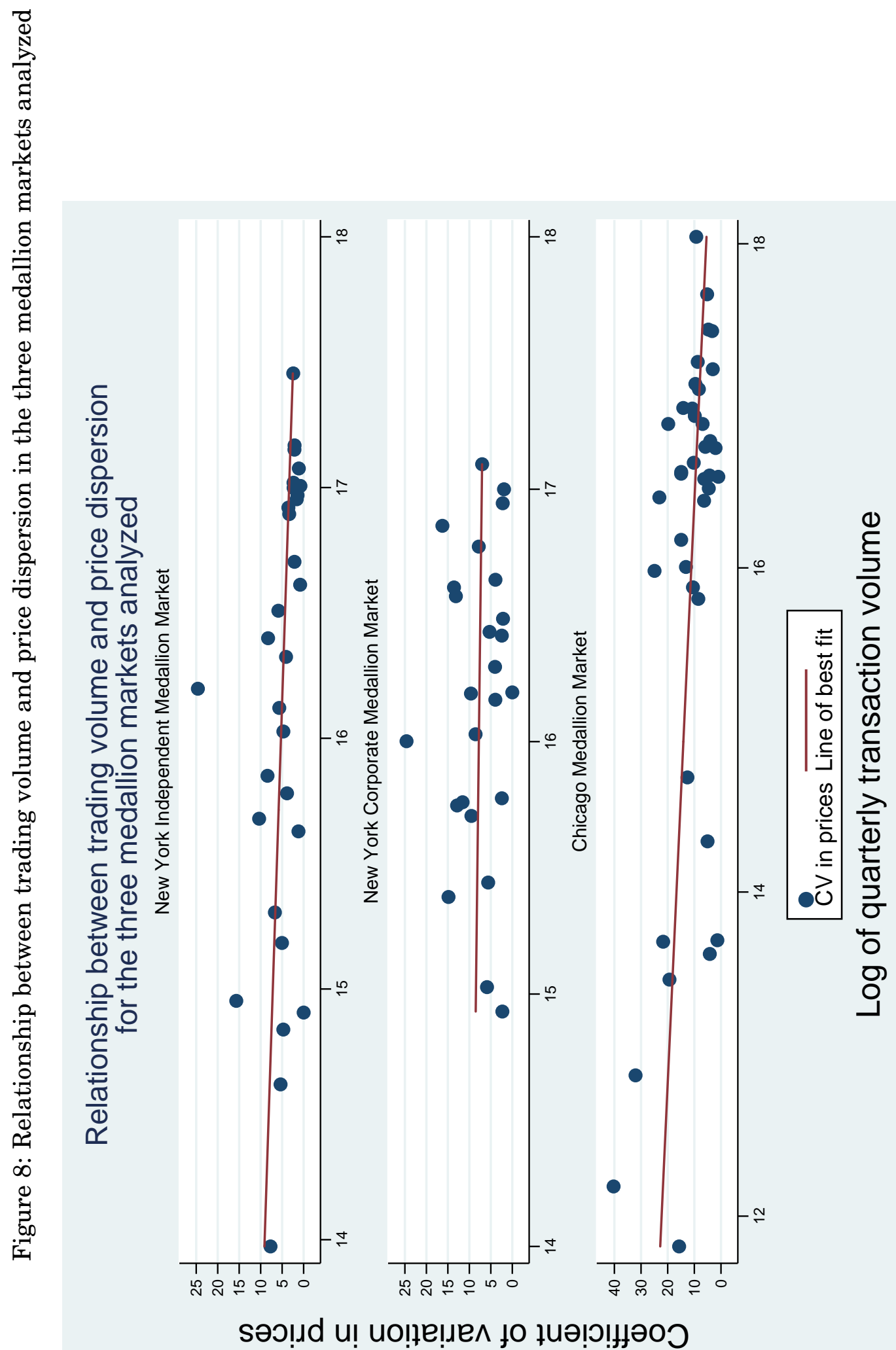

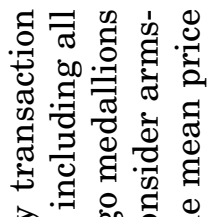
궁요

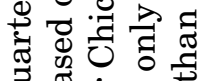
z๘ สี สี

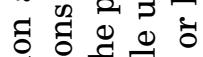
荧䒠击 कृ पे औ. 엉 \& \&

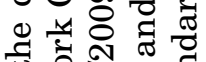
눙

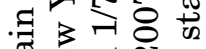
퓽 $\circ$ 定 ब. Q \% कึ है

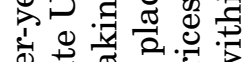

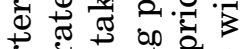
कै थै.

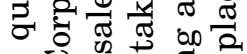
o 范 क 010 कृ

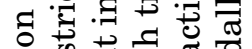

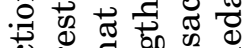
ธू की ॠँ g

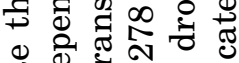
过

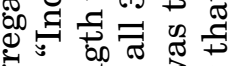

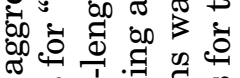

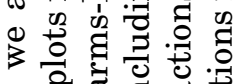
of $\pi$.

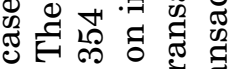
읭 뭉 ङ

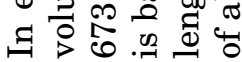


Table 1: Summary statistics for all arms-length transactions involving asset sales of independent and mini-fleet medallions in New York City between May 2009 and December 2016

\begin{tabular}{|c|c|c|c|c|c|}
\hline \multicolumn{6}{|c|}{ Panel A: Independent Medallions } \\
\hline Year & Number of medallions & Mean price & Median price & Std. Deviation & Coefficient of variation \\
\hline 2009 & 88 & $\$ 571,602$ & $\$ 570,000$ & $\$ 11,069$ & $1.9 \%$ \\
\hline 2010 & 169 & $\$ 603,360$ & $\$ 610,000$ & $\$ 19,442$ & $3.2 \%$ \\
\hline 2011 & 186 & $\$ 666,390$ & $\$ 670,000$ & $\$ 23,787$ & $3.6 \%$ \\
\hline 2012 & 107 & $\$ 713,368$ & $\$ 705,000$ & $\$ 33,293$ & $4.7 \%$ \\
\hline 2013 & 58 & $\$ 899,638$ & $\$ 925,000$ & $\$ 148,568$ & $16.5 \%$ \\
\hline 2014 & 50 & $\$ 948,186$ & $\$ 980,000$ & $\$ 67,081$ & $7.1 \%$ \\
\hline 2015 & 16 & $\$ 723,662$ & $\$ 715,000$ & $\$ 54,698$ & $7.6 \%$ \\
\hline 2016 & 25 & $\$ 556,729$ & $\$ 570,000$ & $\$ 61,412$ & $11.0 \%$ \\
\hline Overall & 699 & $\$ 683,309$ & $\$ 660,000$ & $\$ 124,892$ & $18.3 \%$ \\
\hline \multicolumn{6}{|c|}{ Panel B: Mini-fleet Medallions } \\
\hline 2009 & 59 & $\$ 754,224$ & $\$ 750,000$ & $\$ 15,728$ & $2.1 \%$ \\
\hline 2010 & 105 & $\$ 735,451$ & $\$ 775,000$ & $\$ 78,274$ & $10.6 \%$ \\
\hline 2011 & 63 & $\$ 900,083$ & $\$ 950,000$ & $\$ 102,163$ & $11.4 \%$ \\
\hline 2012 & 55 & $\$ 1,003,241$ & $\$ 1,000,000$ & $\$ 109,500$ & $10.9 \%$ \\
\hline 2013 & 21 & $\$ 1,160,500$ & $\$ 1,200,000$ & $\$ 90,996$ & $7.8 \%$ \\
\hline 2014 & 34 & $\$ 1,102,441$ & $\$ 1,175,000$ & $\$ 120,064$ & $10.9 \%$ \\
\hline 2015 & 18 & $\$ 852,500$ & $\$ 875,000$ & $\$ 74,708$ & $8.8 \%$ \\
\hline 2016 & 24 & $\$ 648,005$ & $\$ 625,000$ & $\$ 77,944$ & $12.0 \%$ \\
\hline Overall & 379 & $\$ 860,895$ & $\$ 800,000$ & $\$ 172,954$ & $20.1 \%$ \\
\hline
\end{tabular}

Notes: All 3,237 transactions of New York taxicab medallions occurring between 1/5/2009 and 12/31/2016 were considered for the analysis. Transactions can involve either asset sales or stock transfers. As noted in the text, medallions can be of two types: independent and corporate (or mini-fleet), each of which has three sub-categories: (a) Unrestricted, (b) Alternative Fuel, and (c) Accessible. This table only analyzes asset sales for two specific sub-categories of medallions: "Independent Unrestricted" and "Corporate (or Mini-fleet) Unrestricted." Asset sales for these two specific sub-categories represent 1,467 (or 45\%) of all medallion transactions. Of those 1,467 transactions, we only consider arms-length transactions in compiling these summary statistics. Effectively, that means dropping all transactions taking place at artificially low prices such as $\$ 0, \$ 1$, etc. The rule used was to drop all transactions occurring at prices more than two standard deviations higher or lower than the mean price of all transactions for that sub-category that take place within a quarter. Because of this decision to eliminate all outliers, ultimately the statistics presented in this table are based on transactions involving 699 "Independent Unrestricted" and 379 "Corporate Unrestricted" medallions which represent $33.3 \%$ of all medallions transacted during this period (May 2009-December 2016) but 80.9\% of overall transaction volume. In case of partial transfer of interest (e.g. 50\%), the quoted prices are rescaled by the percentage of interest transferred. For example, if a transaction is reported at a price of $\$ 350,000$, but it involves transferring a 50\% interest in the medallion, the purchase price is calculated as $\$ 700,000$. Data on medallion prices are from the New York City Taxi and Limousine Commission webpage: http://www.nyc.gov/html/tlc/html/about/medallion_transfers.shtml. 


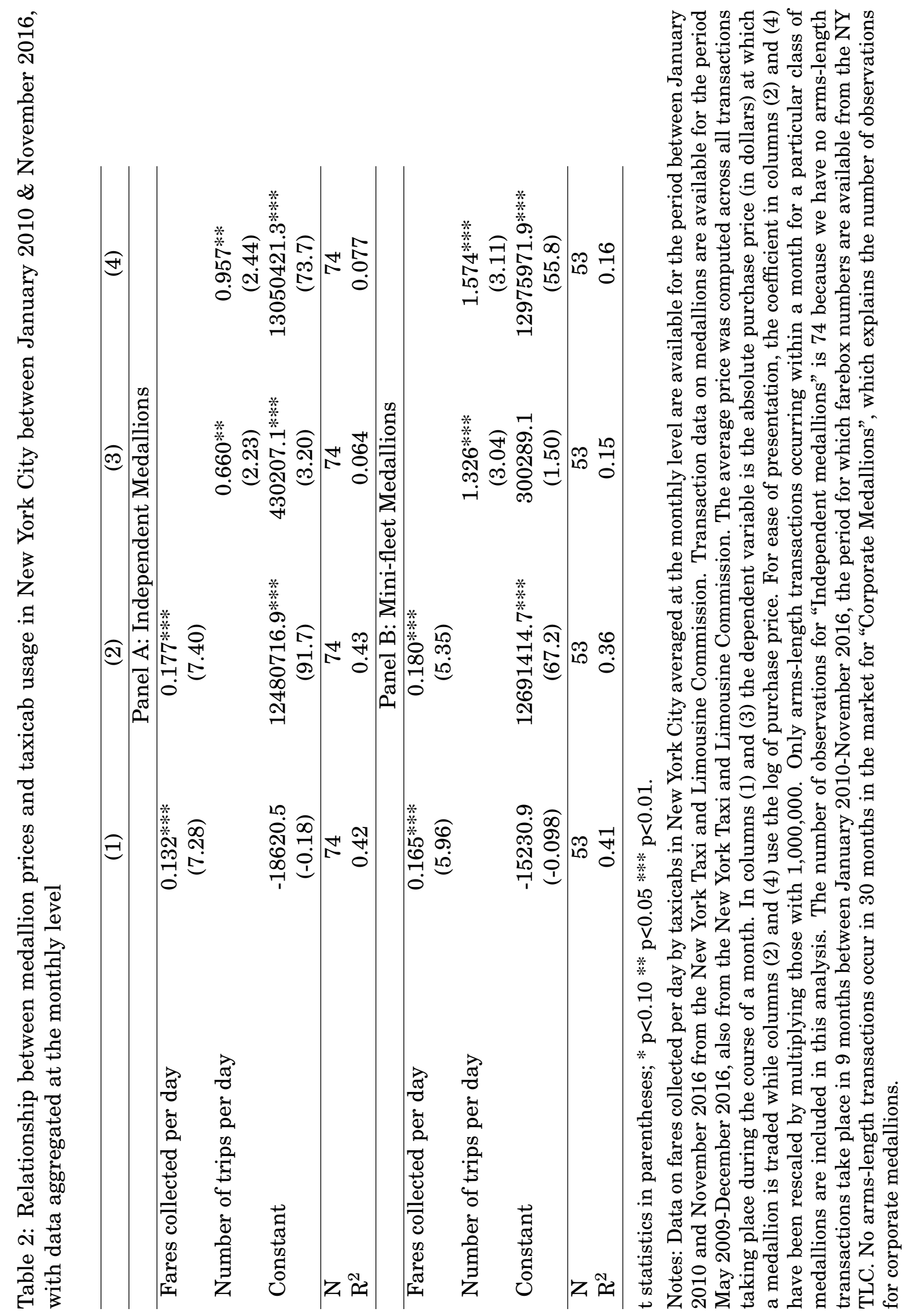




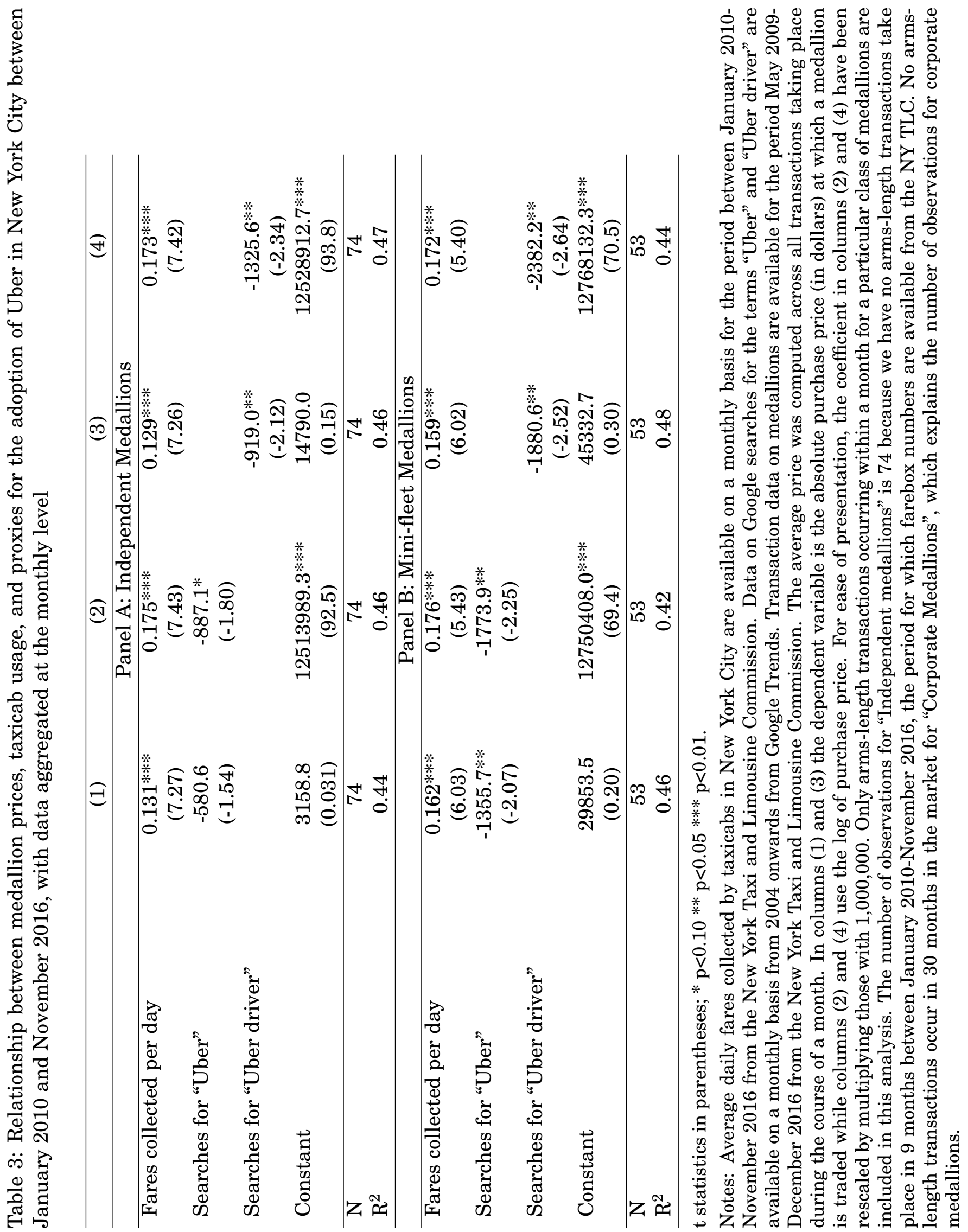


Table 4: Summary statistics for all arms-length transactions involving medallions in the city of Chicago between January 2007 and December 2016

\begin{tabular}{cccccc}
\hline Year & Number of transactions & Mean price & Median price & Std. Deviation & Coefficient of variation \\
\hline 2007 & 605 & $\$ 78,140$ & $\$ 78,000$ & $\$ 18,938$ & $24.2 \%$ \\
2008 & 469 & $\$ 127,785$ & $\$ 126,000$ & $\$ 13,113$ & $10.3 \%$ \\
2009 & 479 & $\$ 171,113$ & $\$ 173,000$ & $\$ 21,354$ & $12.5 \%$ \\
2010 & 354 & $\$ 182,016$ & $\$ 183,000$ & $\$ 6,024$ & $3.3 \%$ \\
2011 & 372 & $\$ 224,868$ & $\$ 235,000$ & $\$ 38,612$ & $17.2 \%$ \\
2012 & 507 & $\$ 337,210$ & $\$ 347,000$ & $\$ 35,809$ & $10.6 \%$ \\
2013 & 361 & $\$ 350,962$ & $\$ 357,000$ & $\$ 14,132$ & $4.0 \%$ \\
2014 & 89 & $\$ 330,581$ & $\$ 325,000$ & $\$ 25,732$ & $7.8 \%$ \\
2015 & 12 & $\$ 243,083$ & $\$ 252,000$ & $\$ 46,915$ & $19.3 \%$ \\
2016 & 30 & $\$ 61,717$ & $\$ 60,000$ & $\$ 10,779$ & $17.5 \%$ \\
\hline Overall & 3,278 & $\$ 204,121$ & $\$ 181,500$ & $\$ 101,697$ & $49.8 \%$ \\
\hline
\end{tabular}

Notes: All 3,457 transactions of Chicago taxicab medallions occurring between 1/1/2007 and 12/31/2016 were considered for the analysis. However, only arms-length transactions were included in compiling these summary statistics. Effectively, that means dropping all transactions taking place at artificially low prices such as $\$ 0, \$ 1$, etc. The rule used was to drop all transactions occurring at prices more than two standard deviations higher or lower than the mean price of all transactions taking place within a quarter. Because of this decision to eliminate all outliers, the statistics presented in this table are based on 3,278 transactions which represent $94.8 \%$ of all transactions and 98.4\% of all transaction volume. Data on medallion prices for 2007-2010 are from The Chicago Dispatcher webpage, http://chicagodispatcher.com/chicago-taxicab-medallion-prices-p235-117.htm, while data from 2011-2016 are from the Department of Business Affairs and Consumer Protection webpage: https://www.cityofchicago.org/city/en/depts/bacp/supp_info/medallion_owner_information.html. 


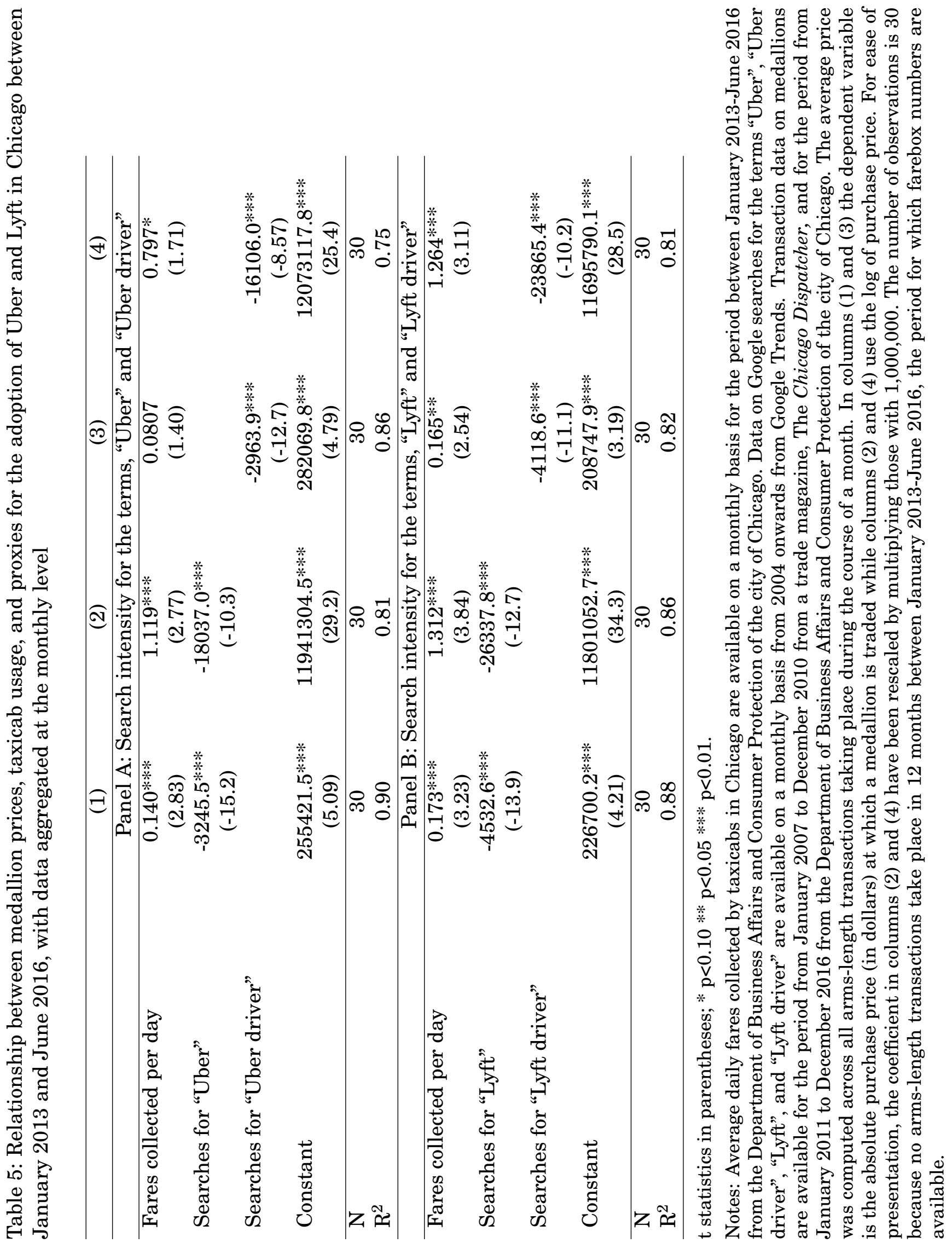




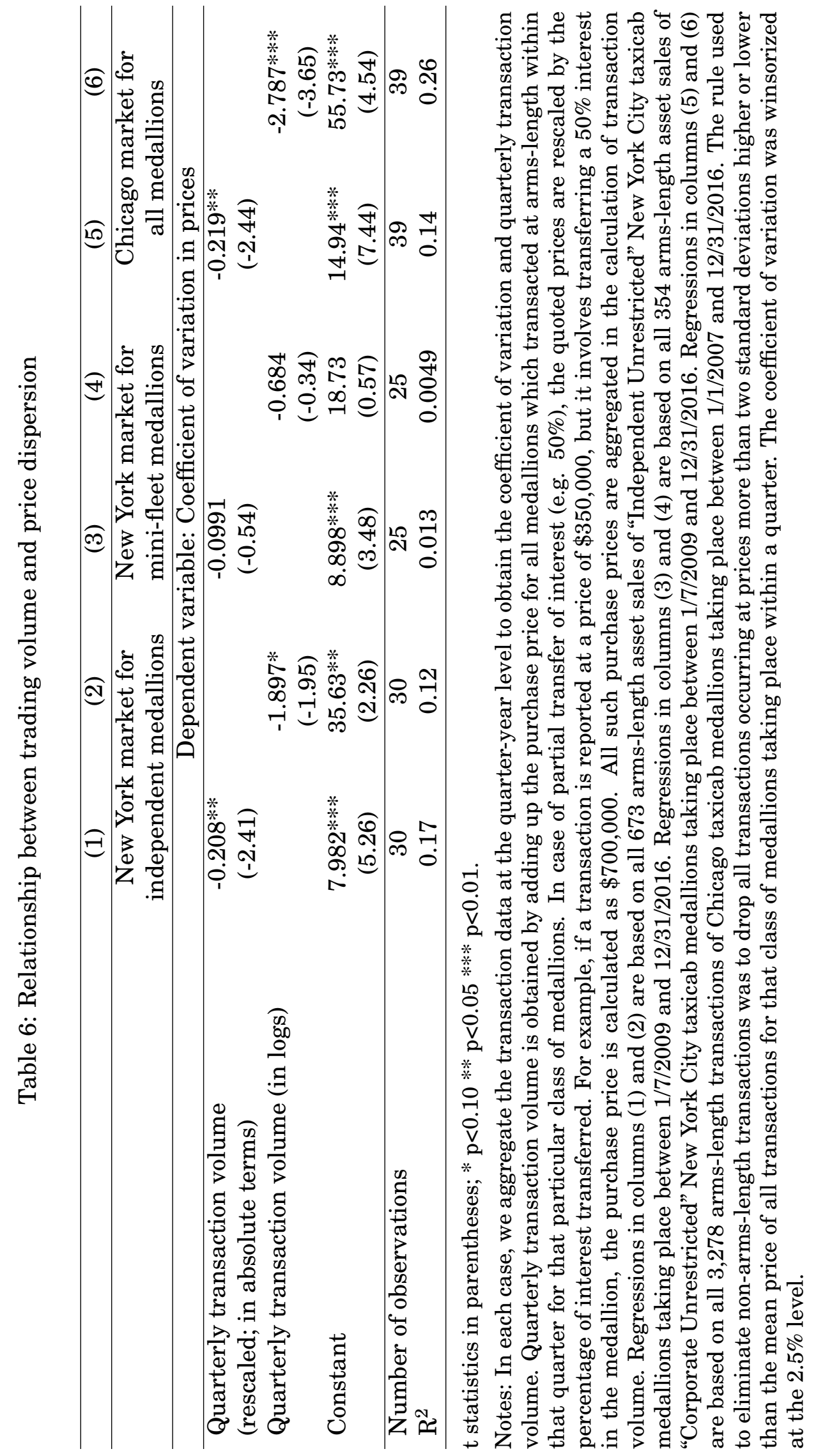




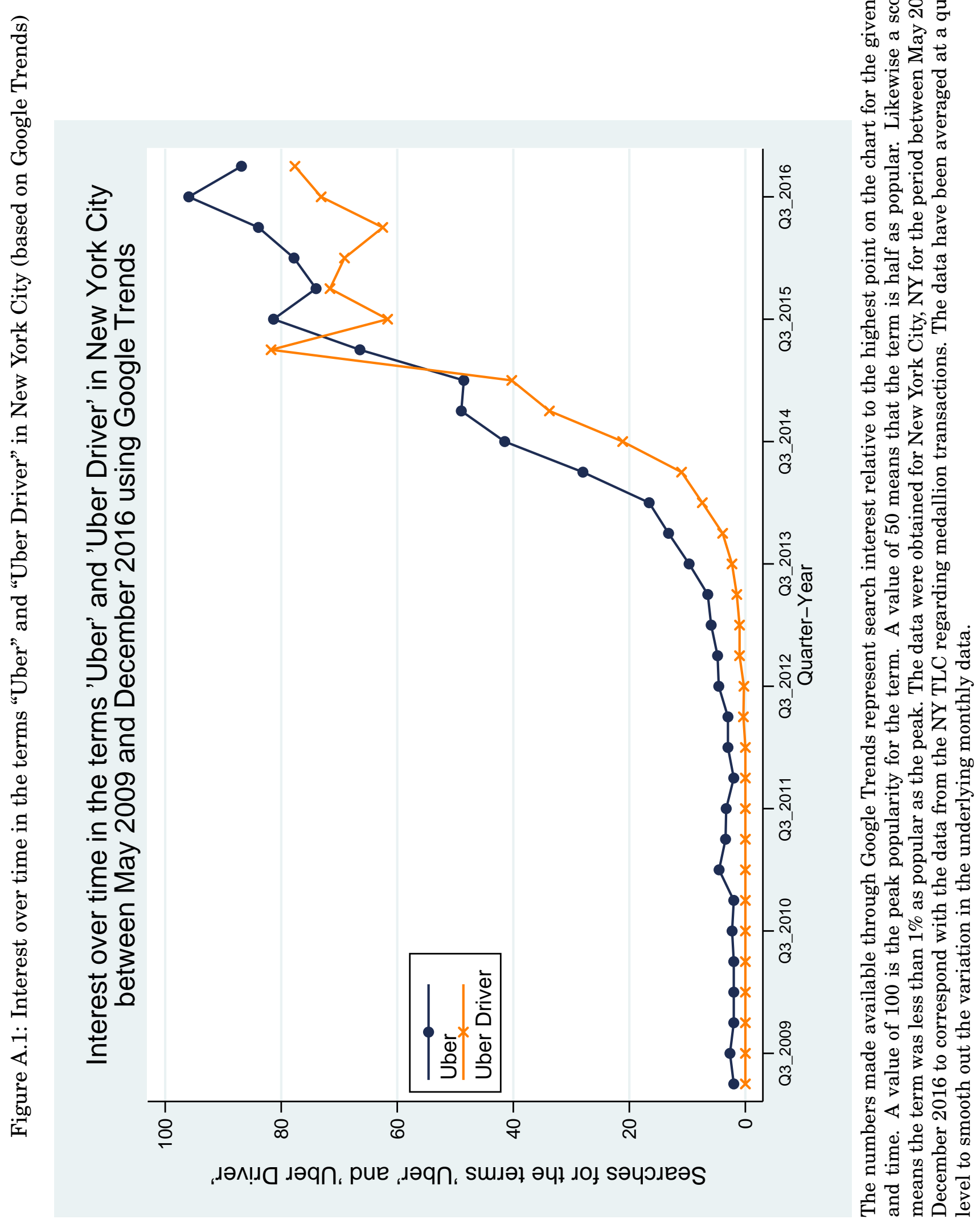




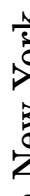

.

今

पै

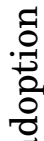

$\stackrel{0}{1}$

कृ

$\cdot \frac{0}{x}$

굴

영

ชี

ลง

क人

?2

สิ

岗

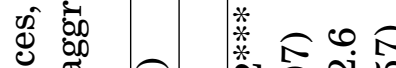

㺼 ส

2.

동 त्व

寻

ত্ত

⿷

ఫี

䒝

율

㝴

.ृ̊ำ

$\pi$

बำ

‥ 우

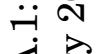

崩

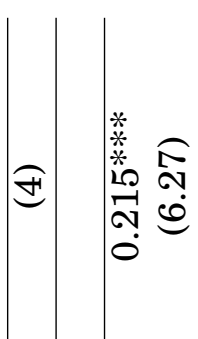

क्ञ

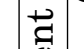

E

ค

苟

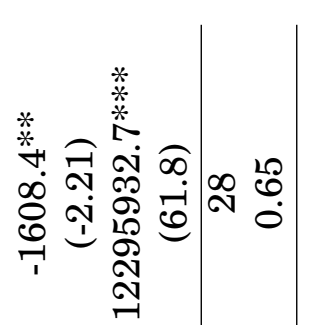

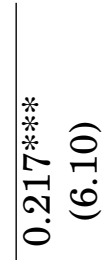

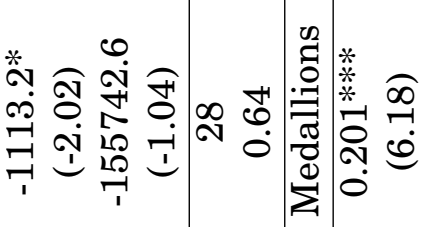

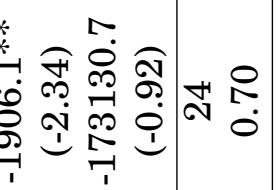
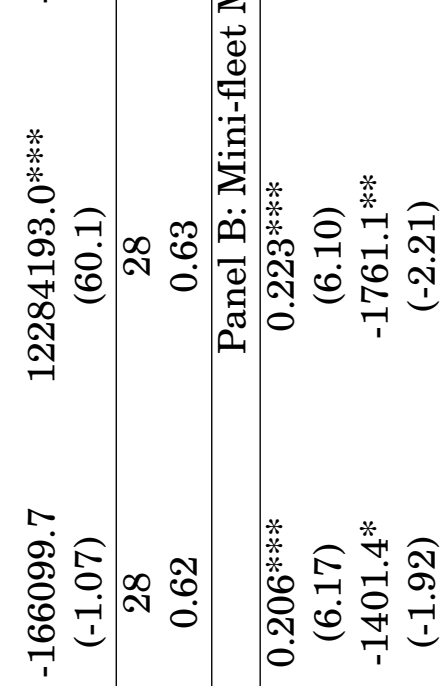

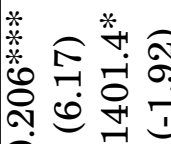

政

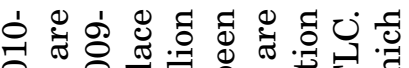

จे क्ष

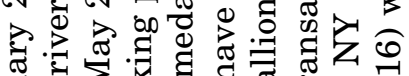

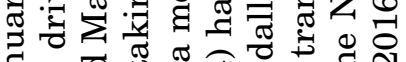

두워

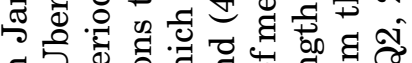

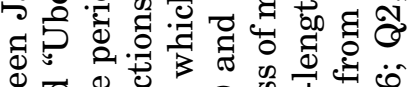

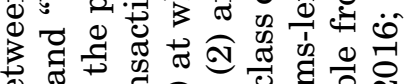

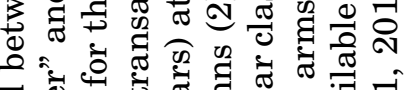

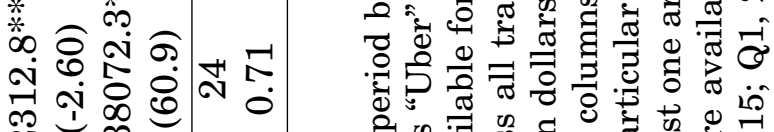

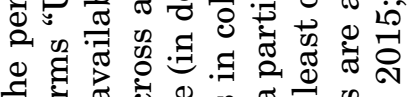

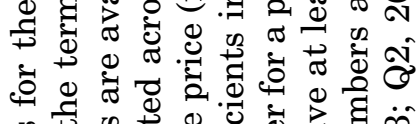

品 wo

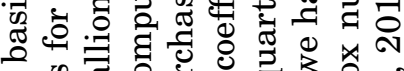

w

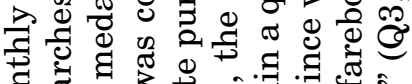

政

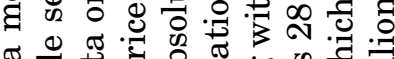

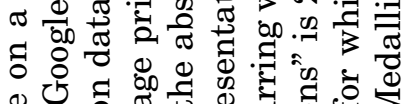
용.

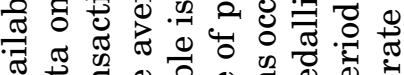

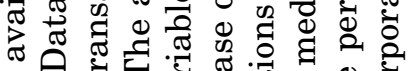
\%

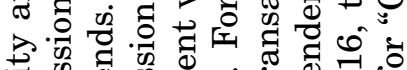

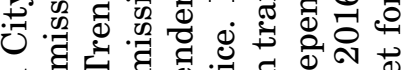
다의

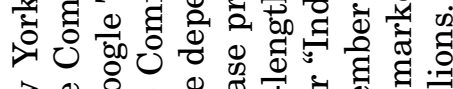
궁 o o

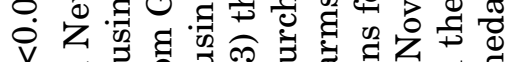
‥ wo

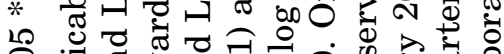
응 댑 v

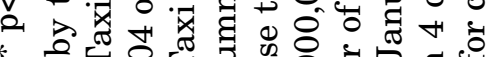

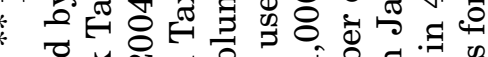
웡

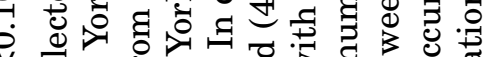
居 34 2 잉 is w 要 0

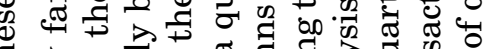

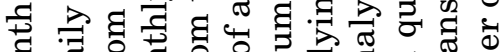

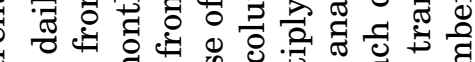

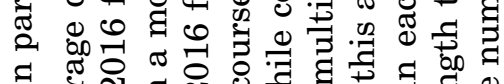

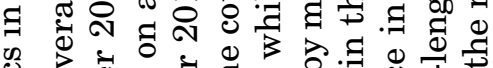

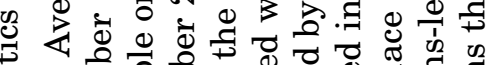

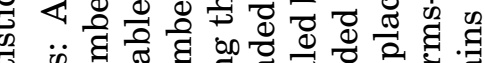

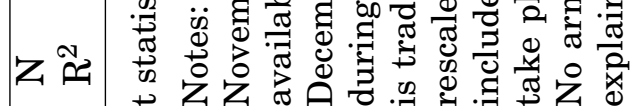




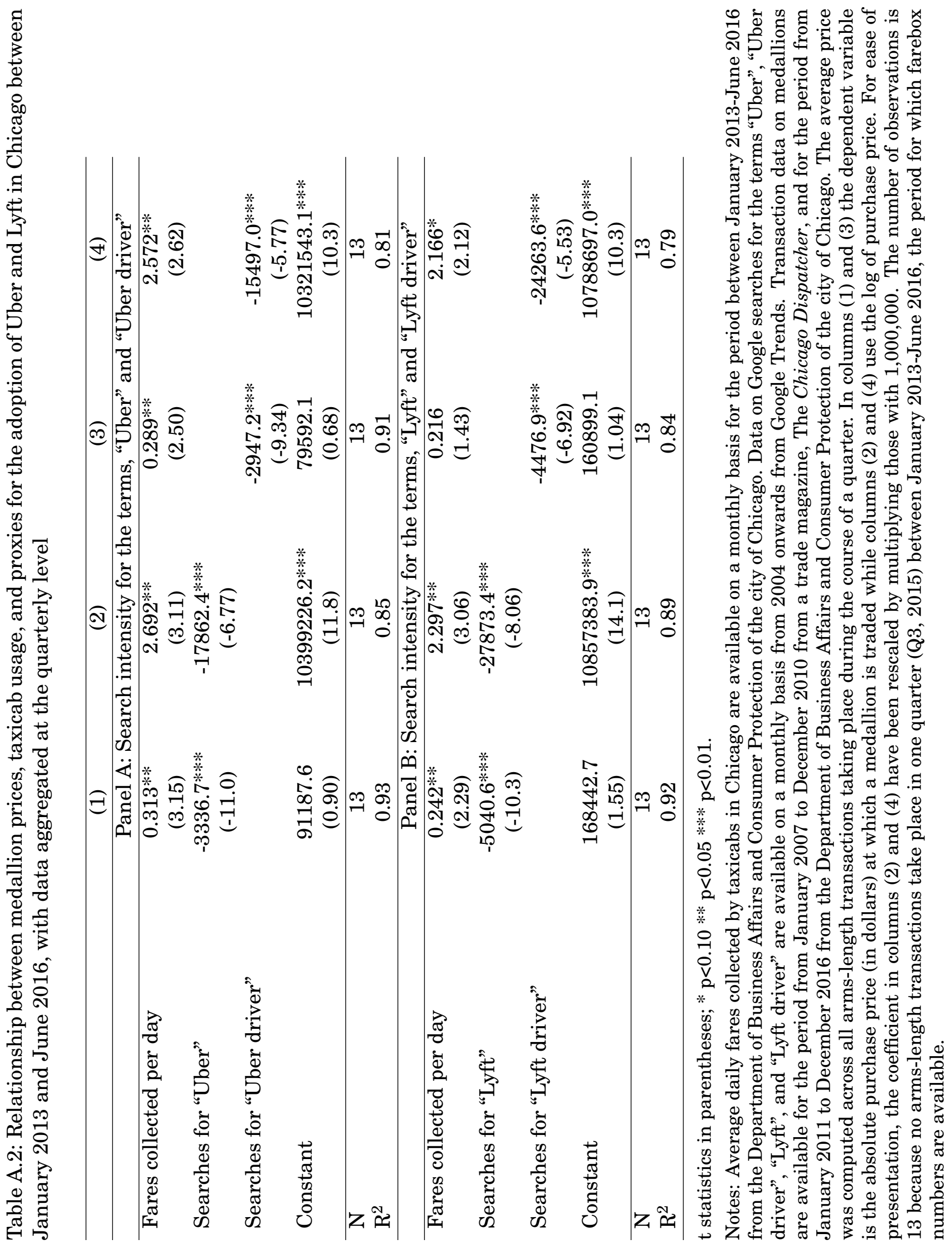

